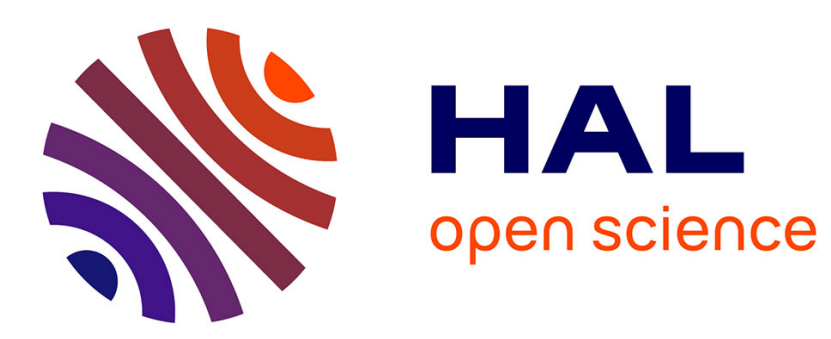

\title{
Subject, Tense and Truth: Towards a Modular Approach to Binding
}

Pierre Pica

\section{To cite this version:}

Pierre Pica. Subject, Tense and Truth: Towards a Modular Approach to Binding. Jacqueline Guéron, Hans-Georg Obenauer, Jean-Yves Pollock. Grammatical Representation, Foris, pp.259-292, 1984, Studies in generative Grammar. halshs-00216079

\section{HAL Id: halshs-00216079 https://shs.hal.science/halshs-00216079}

Submitted on 22 Jan 2009

HAL is a multi-disciplinary open access archive for the deposit and dissemination of scientific research documents, whether they are published or not. The documents may come from teaching and research institutions in France or abroad, or from public or private research centers.
L'archive ouverte pluridisciplinaire HAL, est destinée au dépôt et à la diffusion de documents scientifiques de niveau recherche, publiés ou non, émanant des établissements d'enseignement et de recherche français ou étrangers, des laboratoires publics ou privés. 

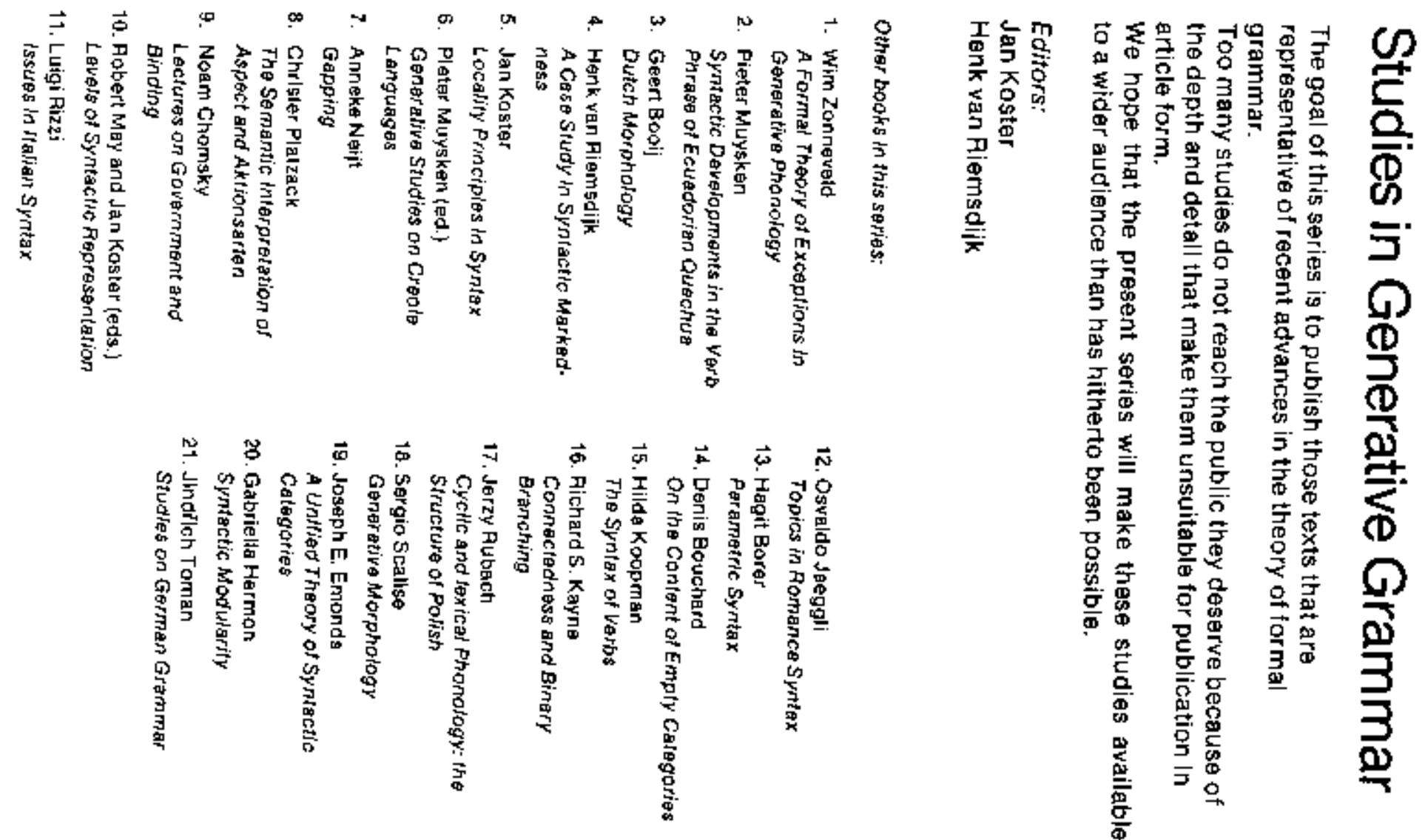

号总总



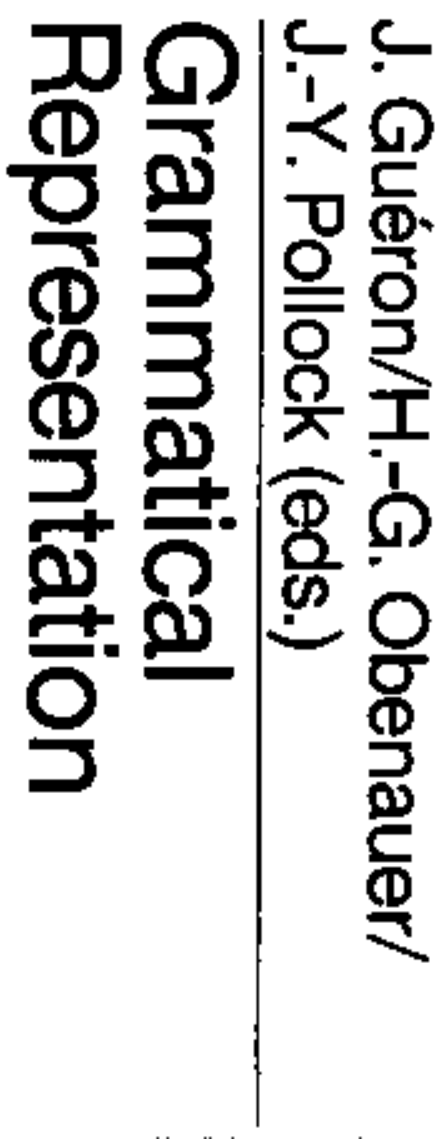




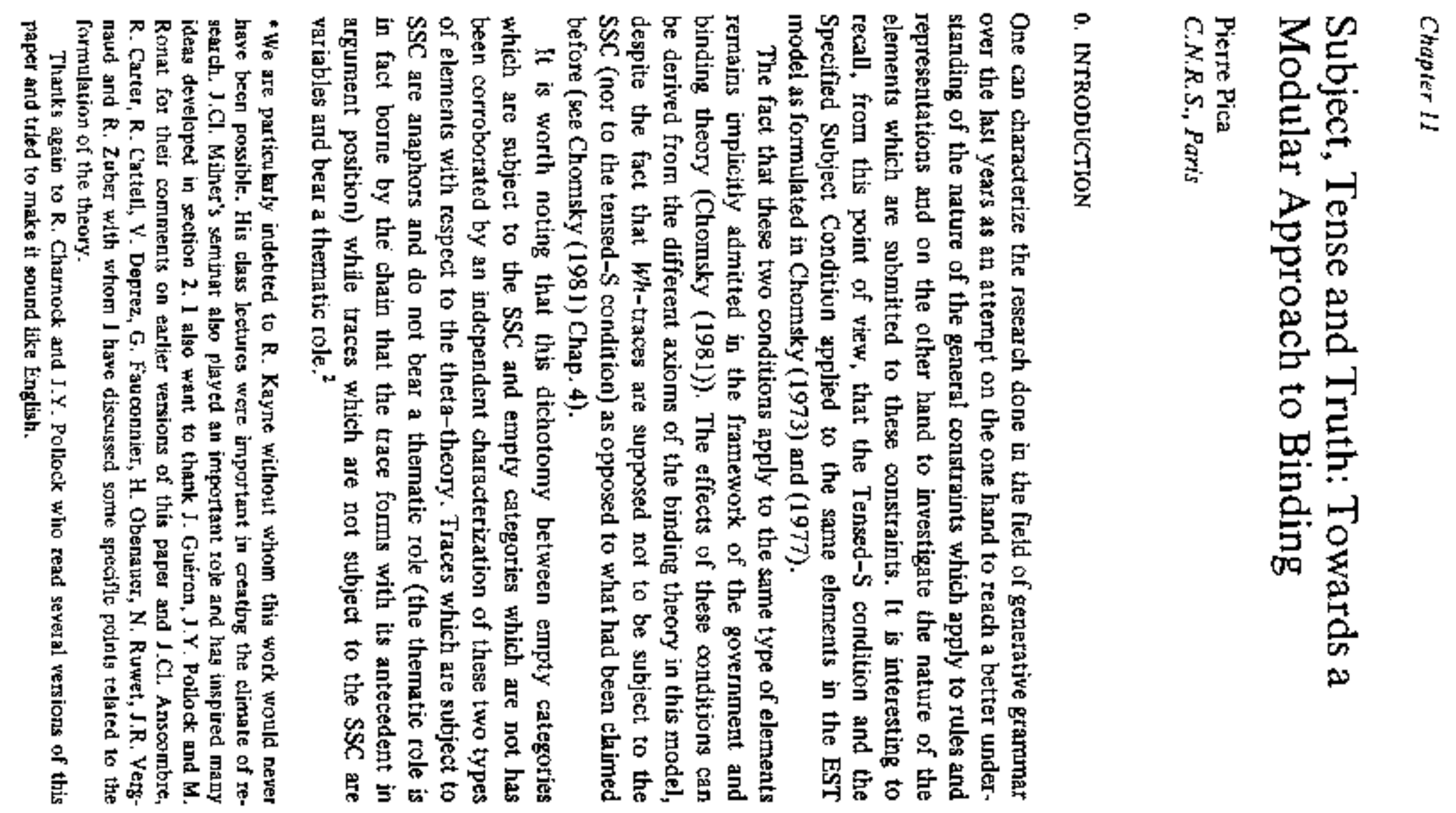




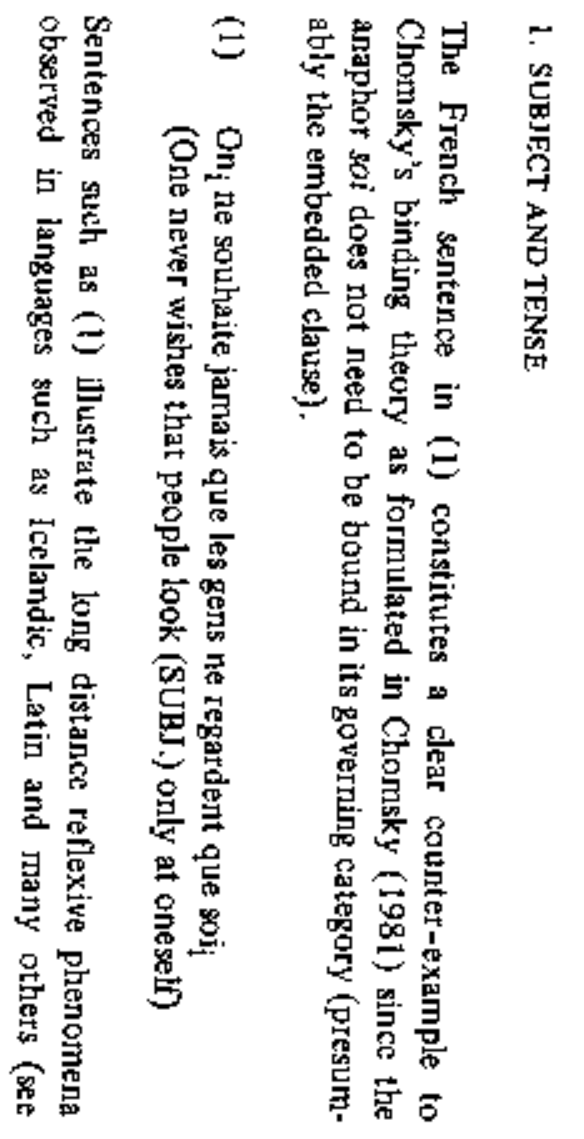

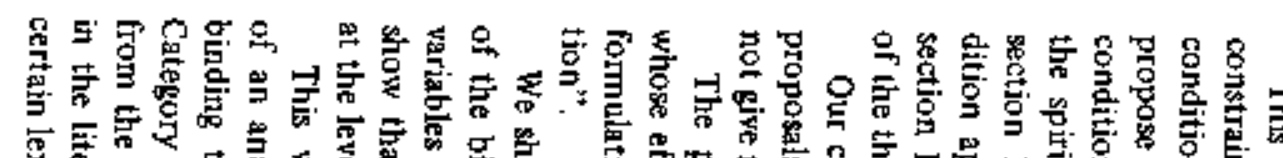

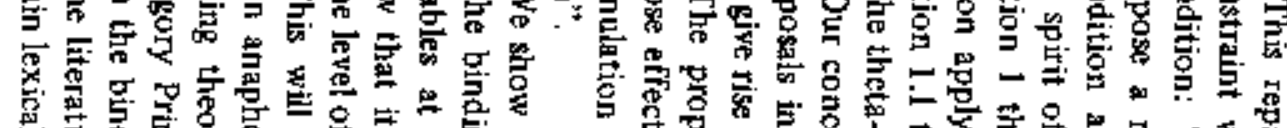

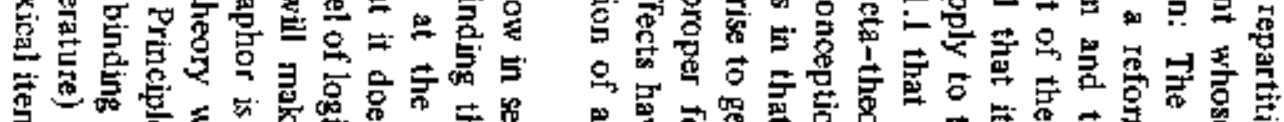

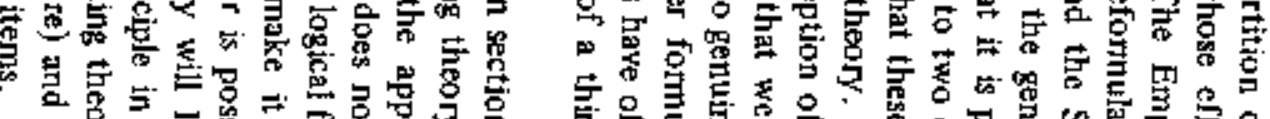

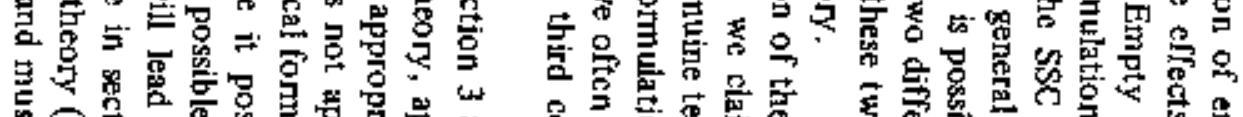

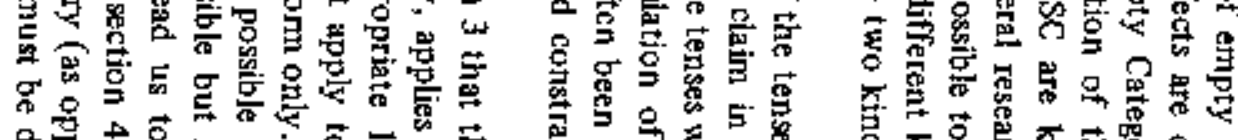

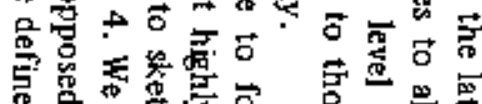

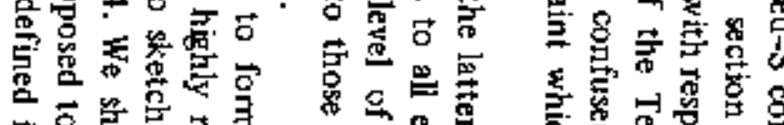
s.

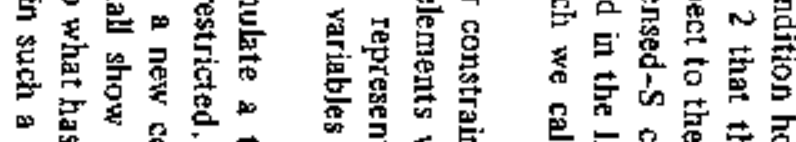

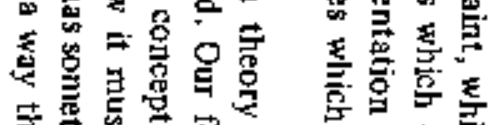
Q

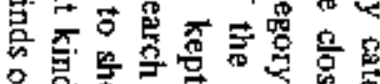

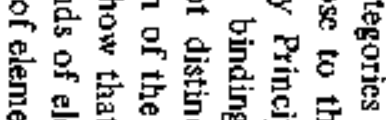

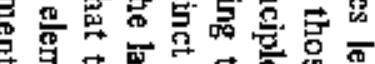

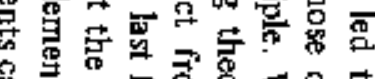

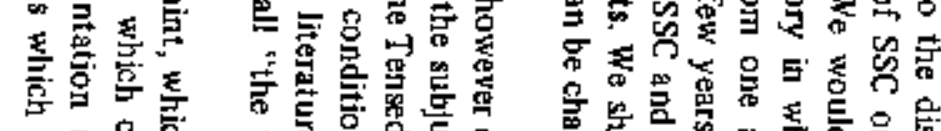

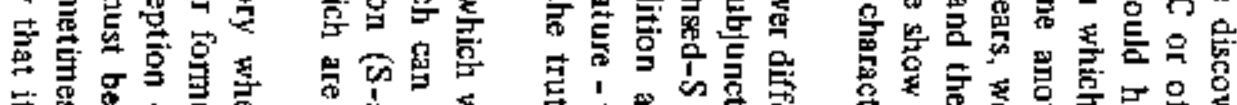

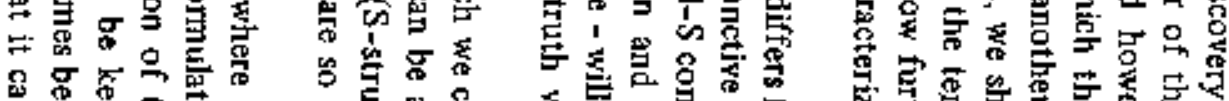

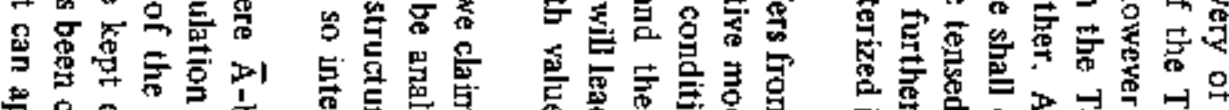

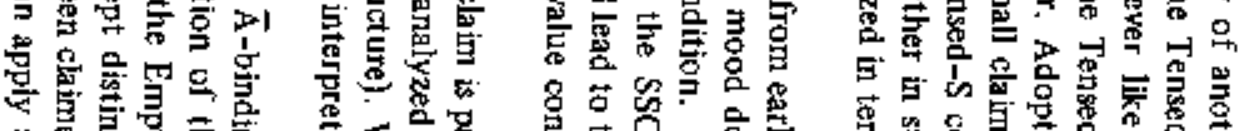

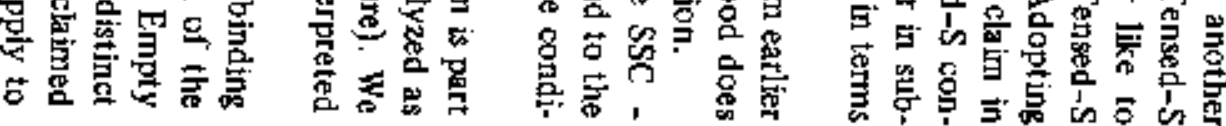
落 武 

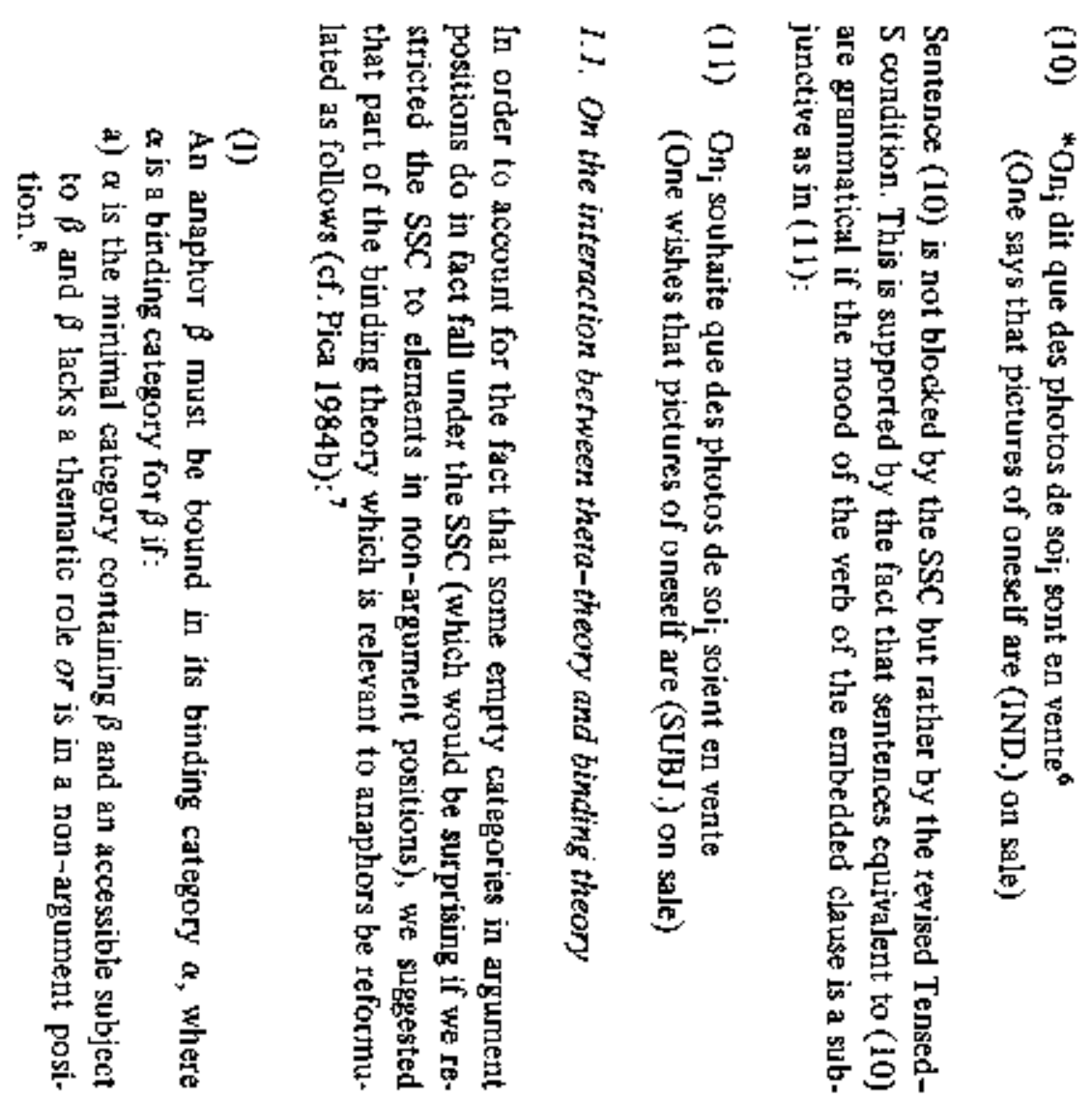

क

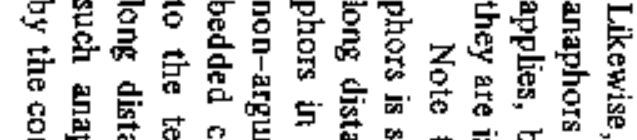

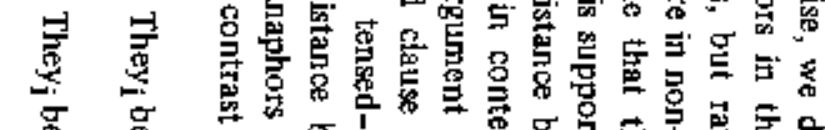

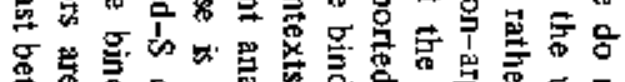

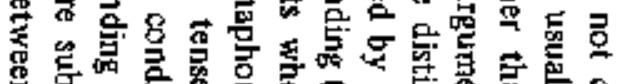

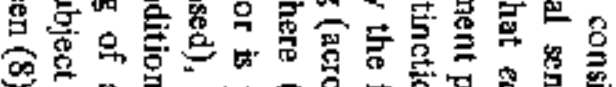

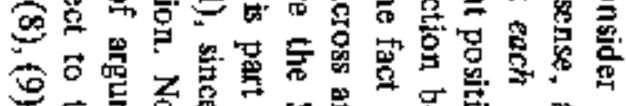

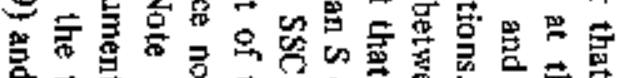

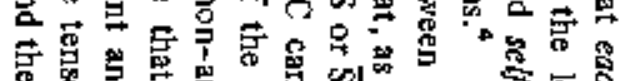

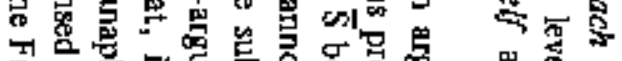

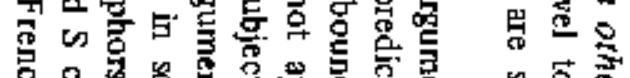

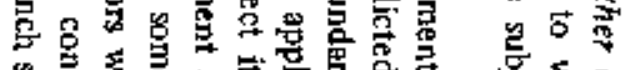

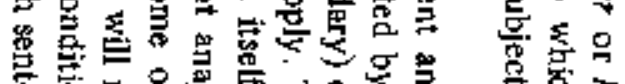

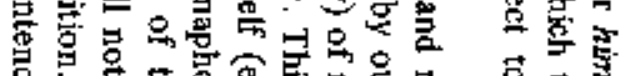

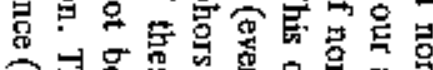

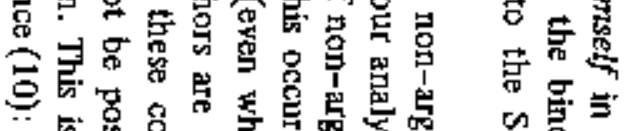

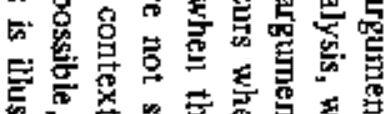

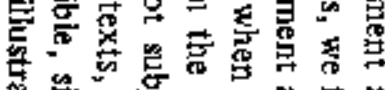

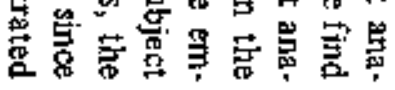

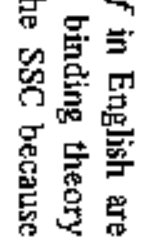

\begin{tabular}{|c|c|c|c|c|c|c|c|c|}
\hline 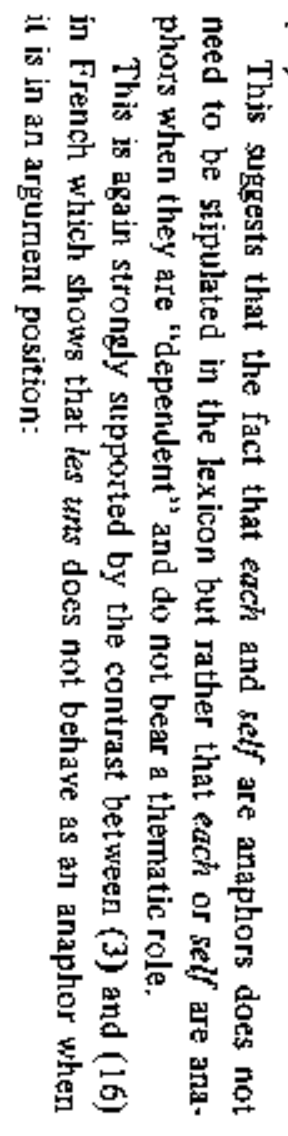 & 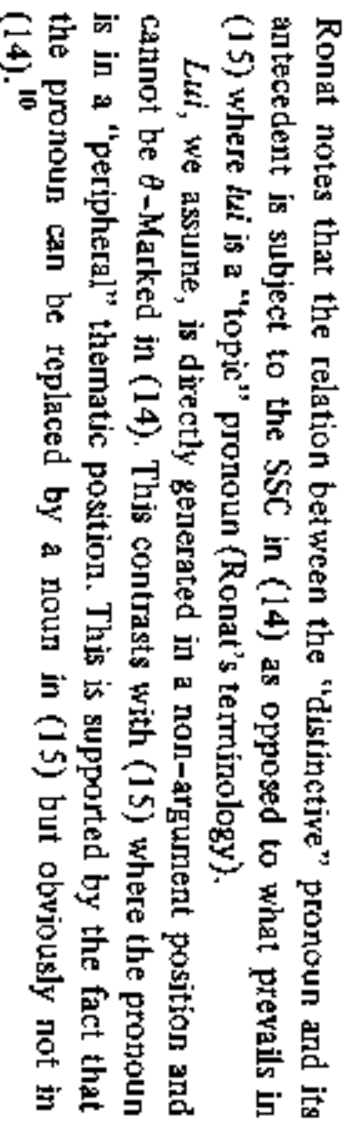 & 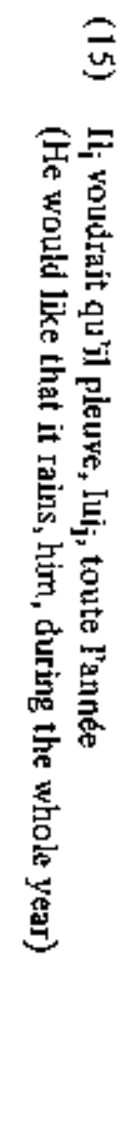 & 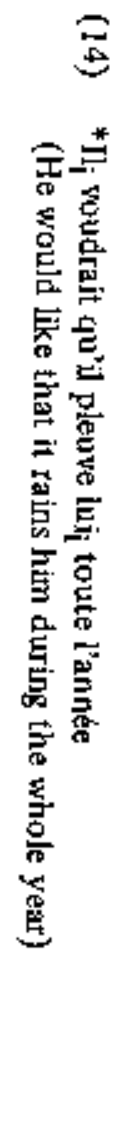 & 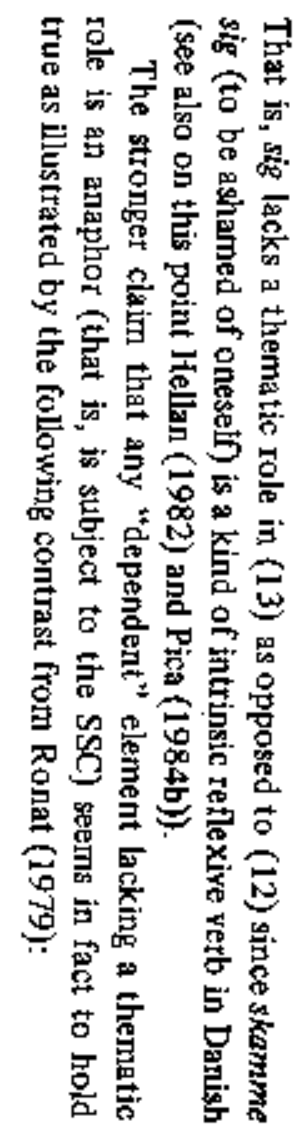 & 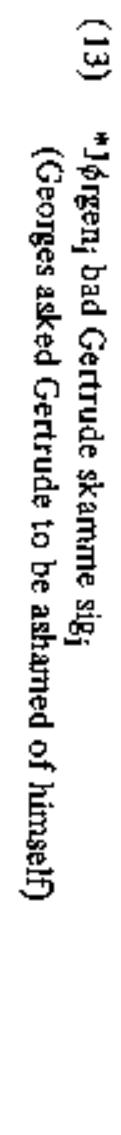 & 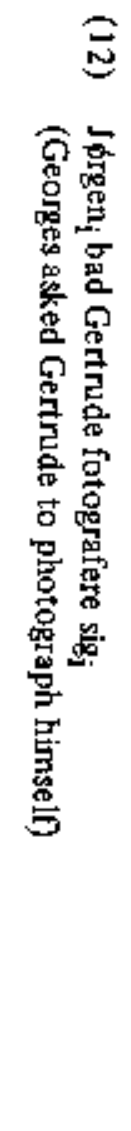 & 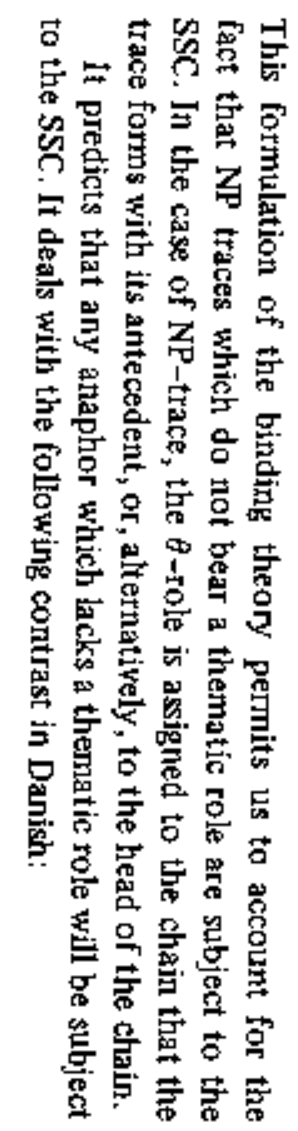 & 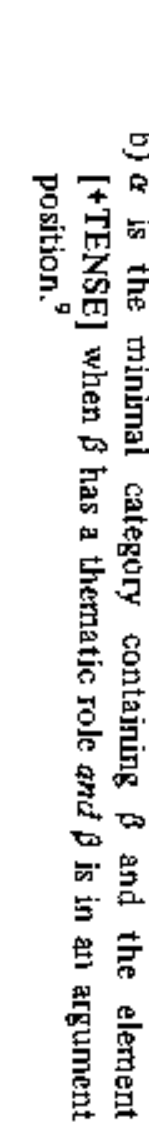 \\
\hline
\end{tabular}




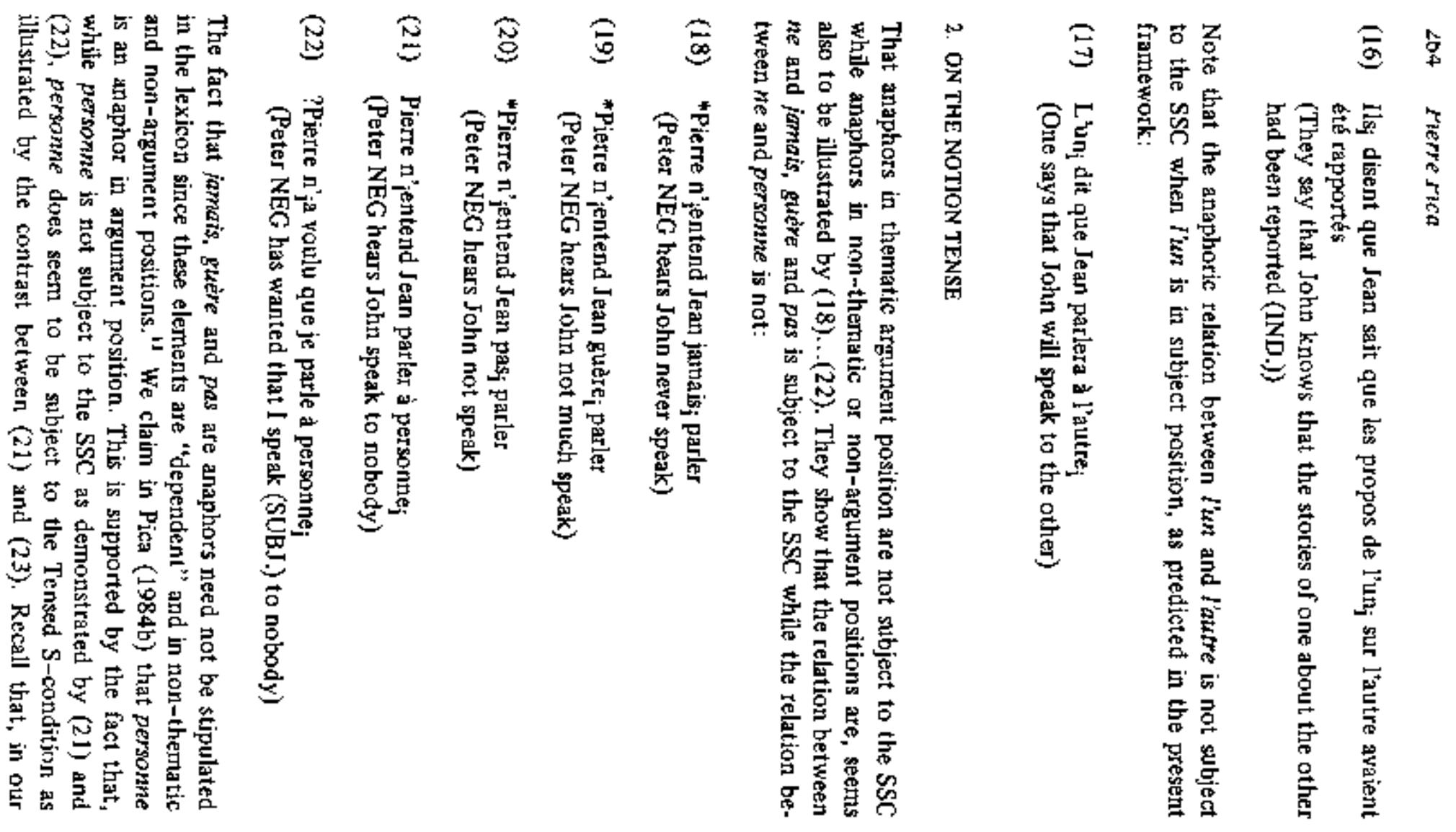

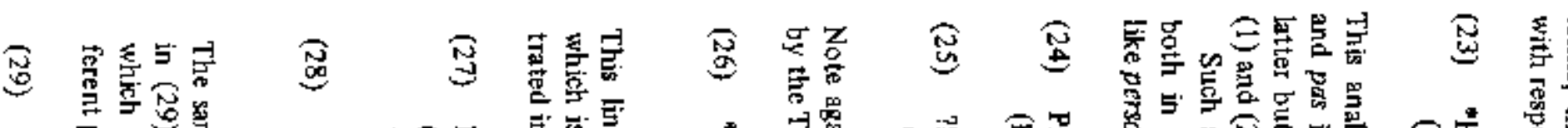

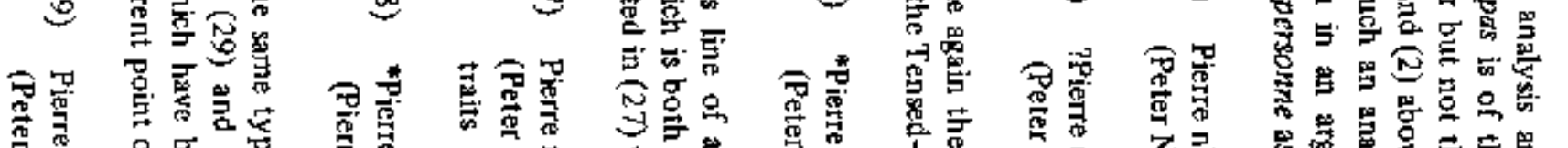

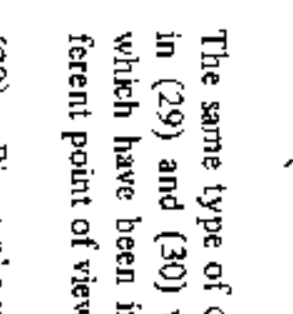

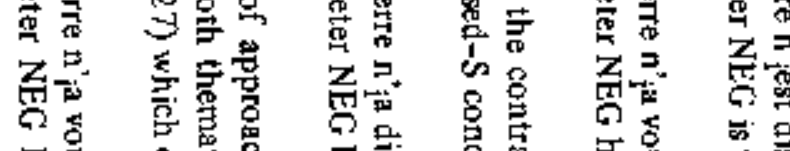

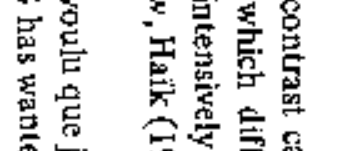

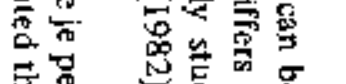

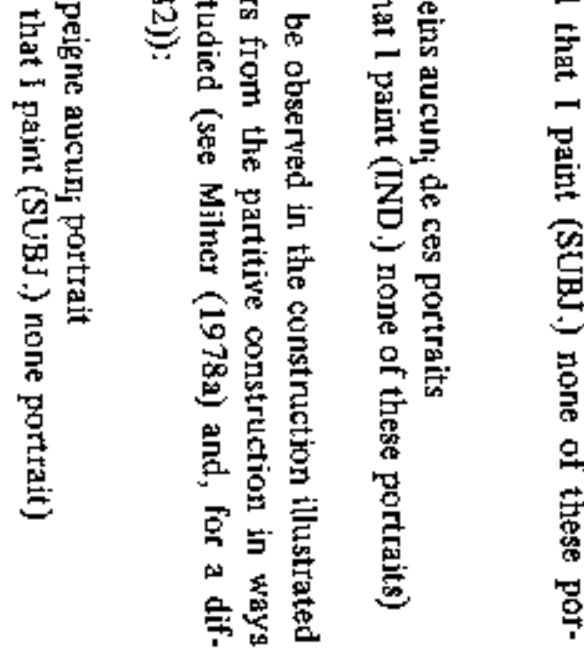

䔶

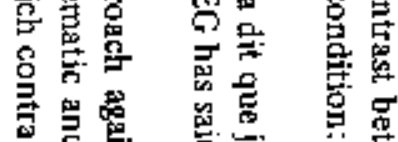

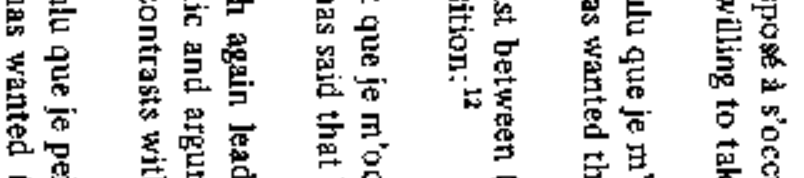

窎总

豆产

兽量

㤩

菟

\section{必憵战}

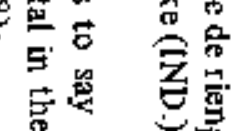

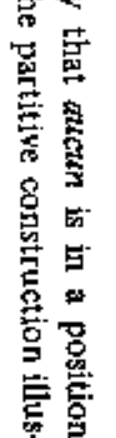

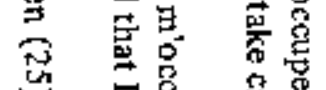

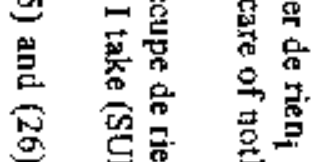

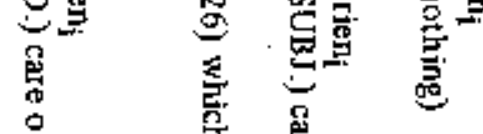

总要要官总

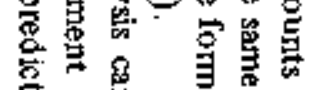
密总

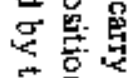

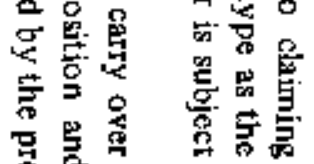

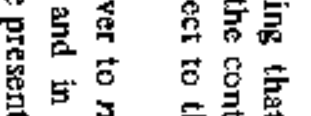

蛋 究考

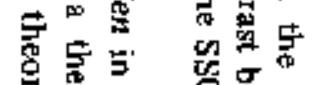

焉

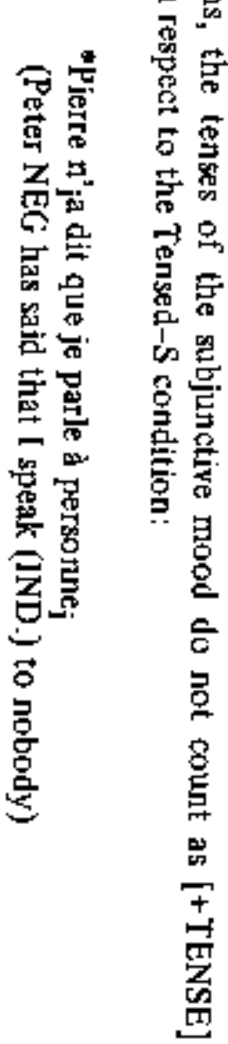




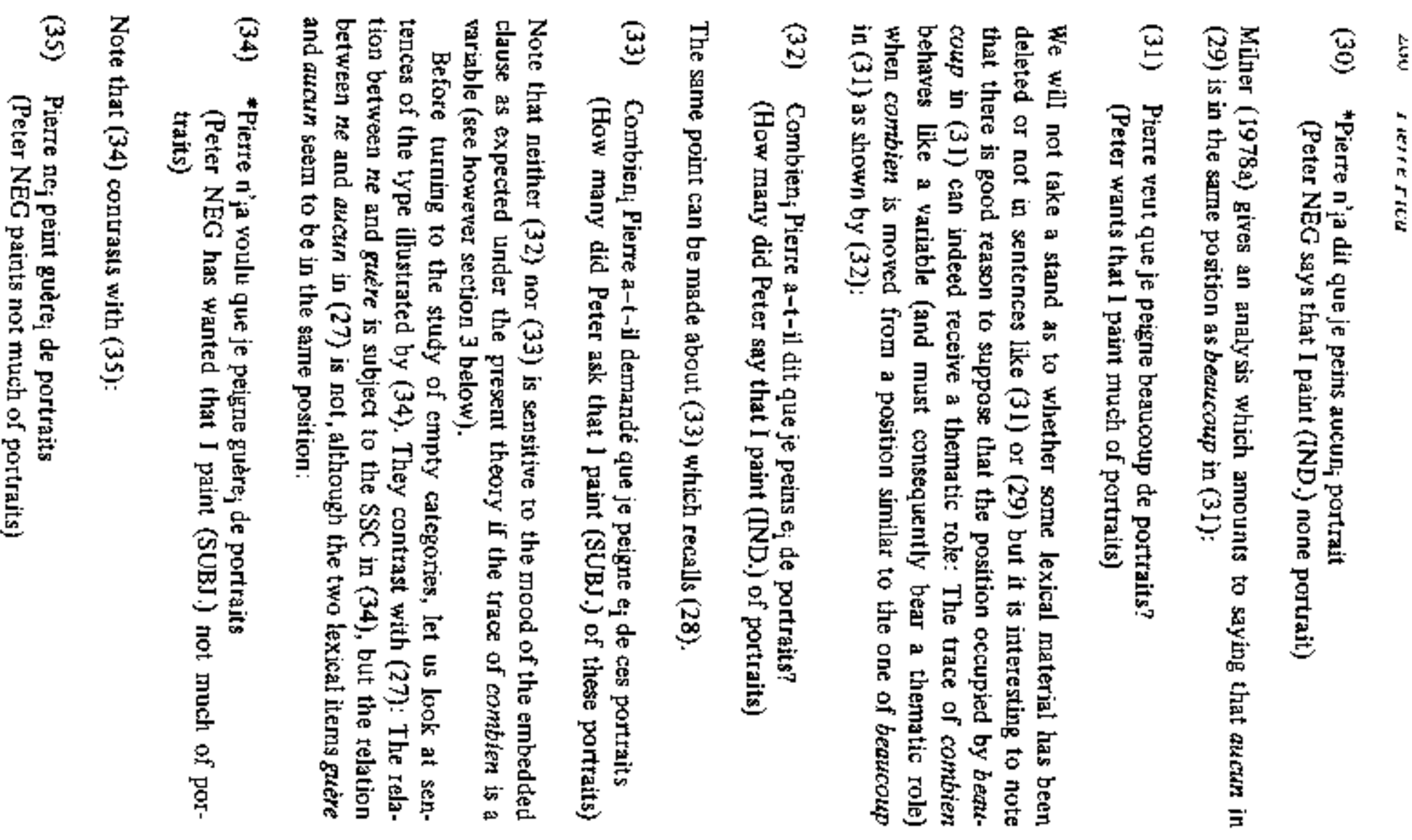

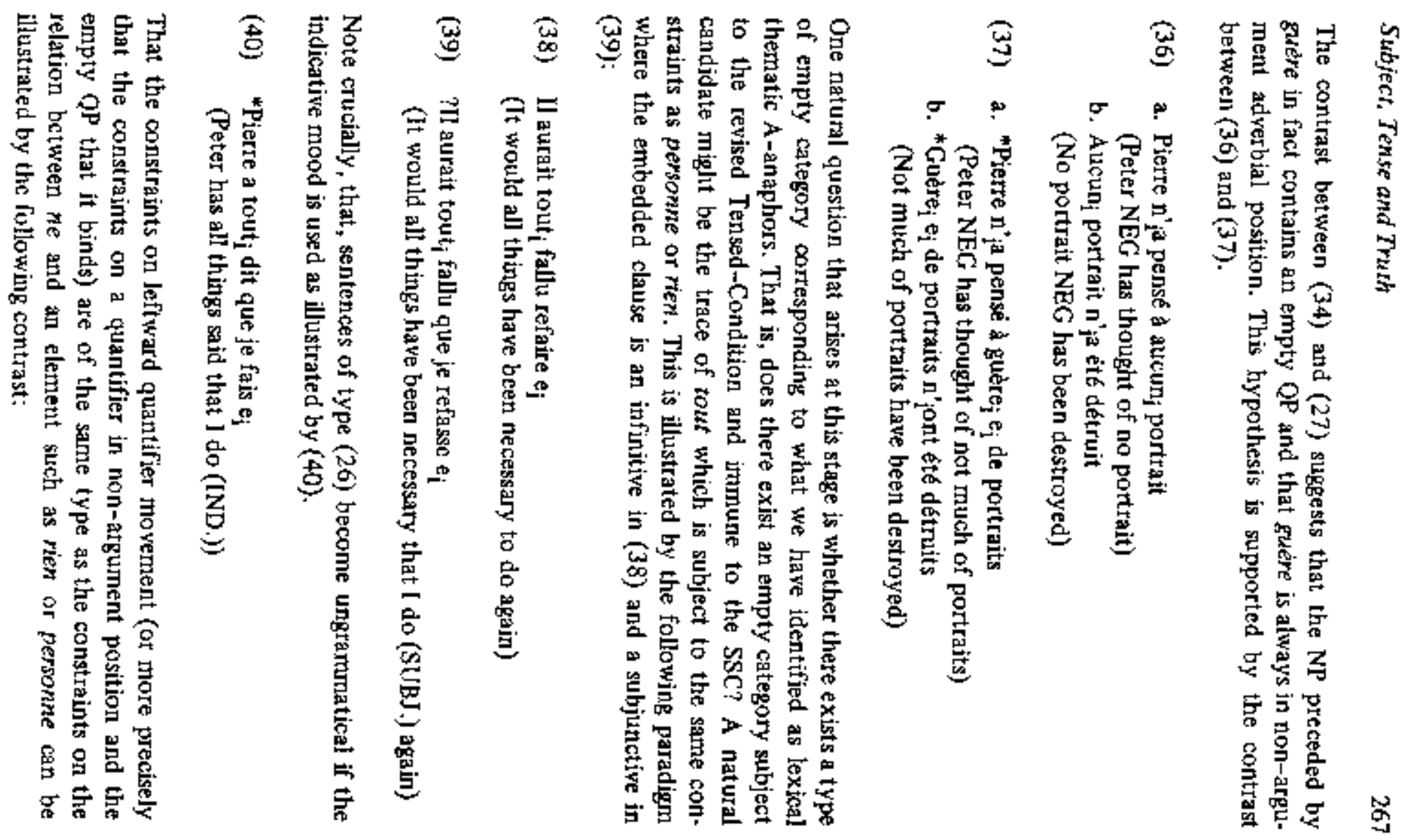



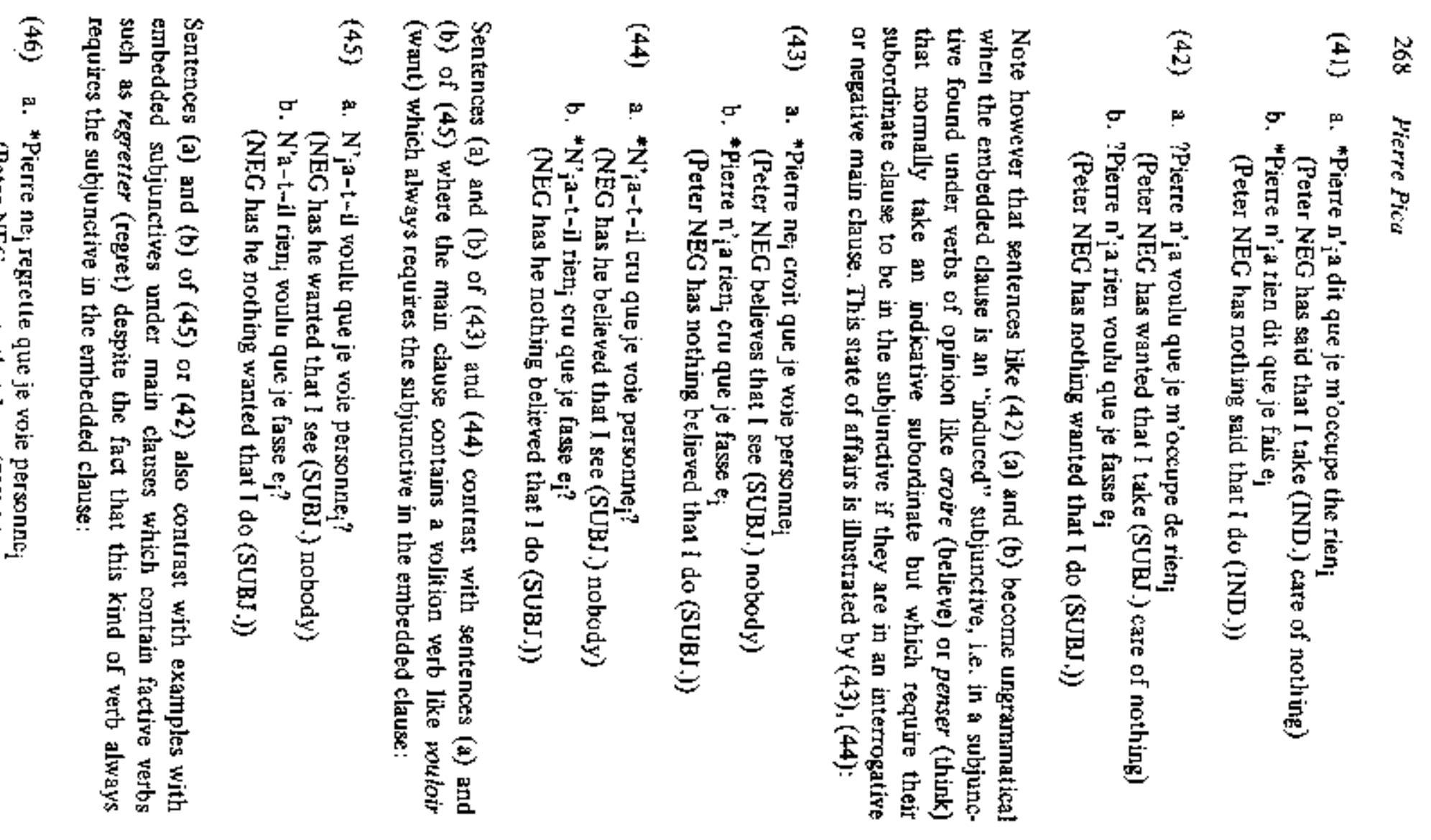

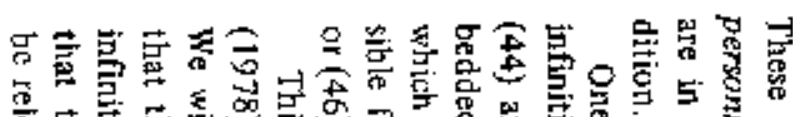

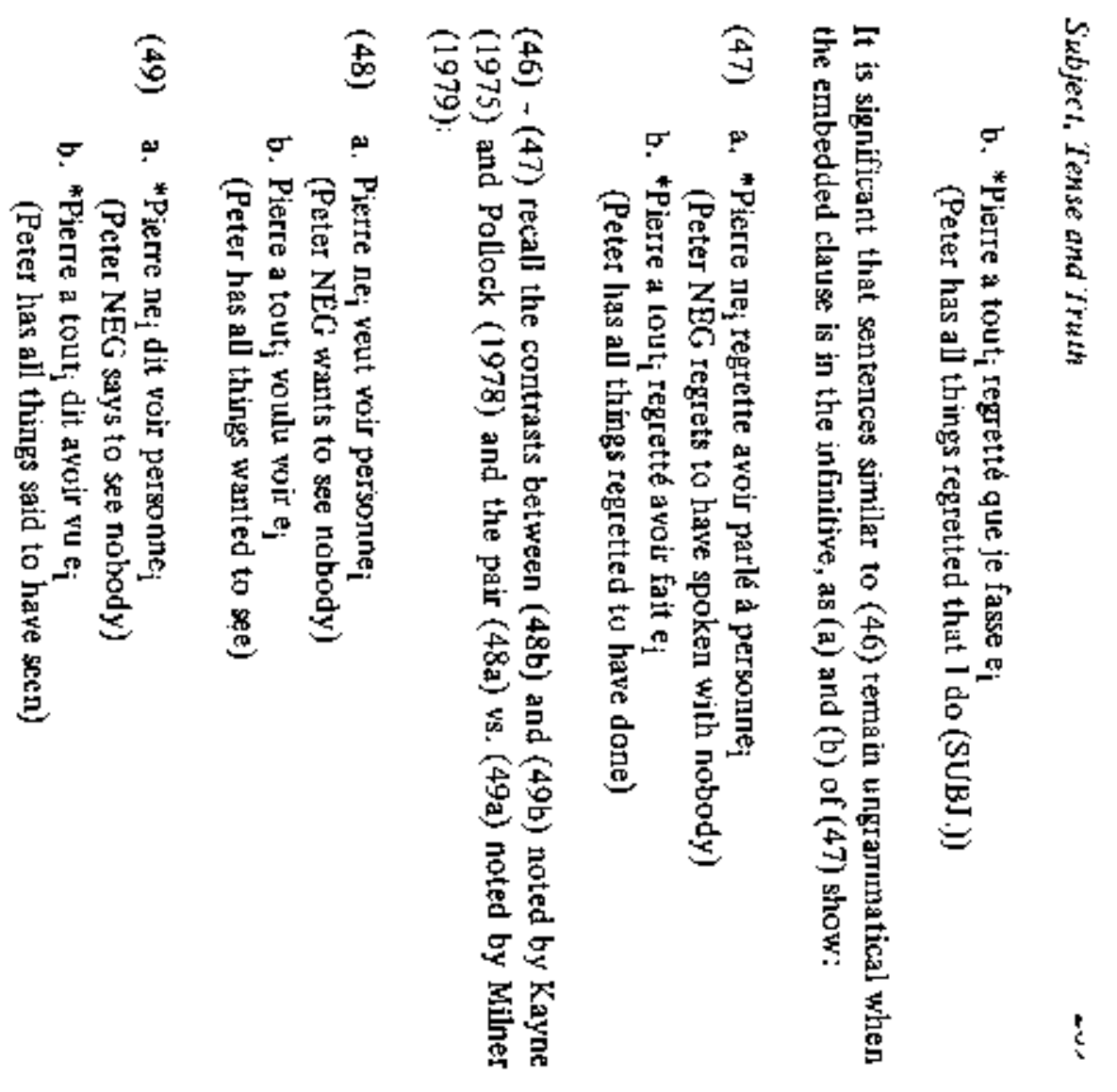




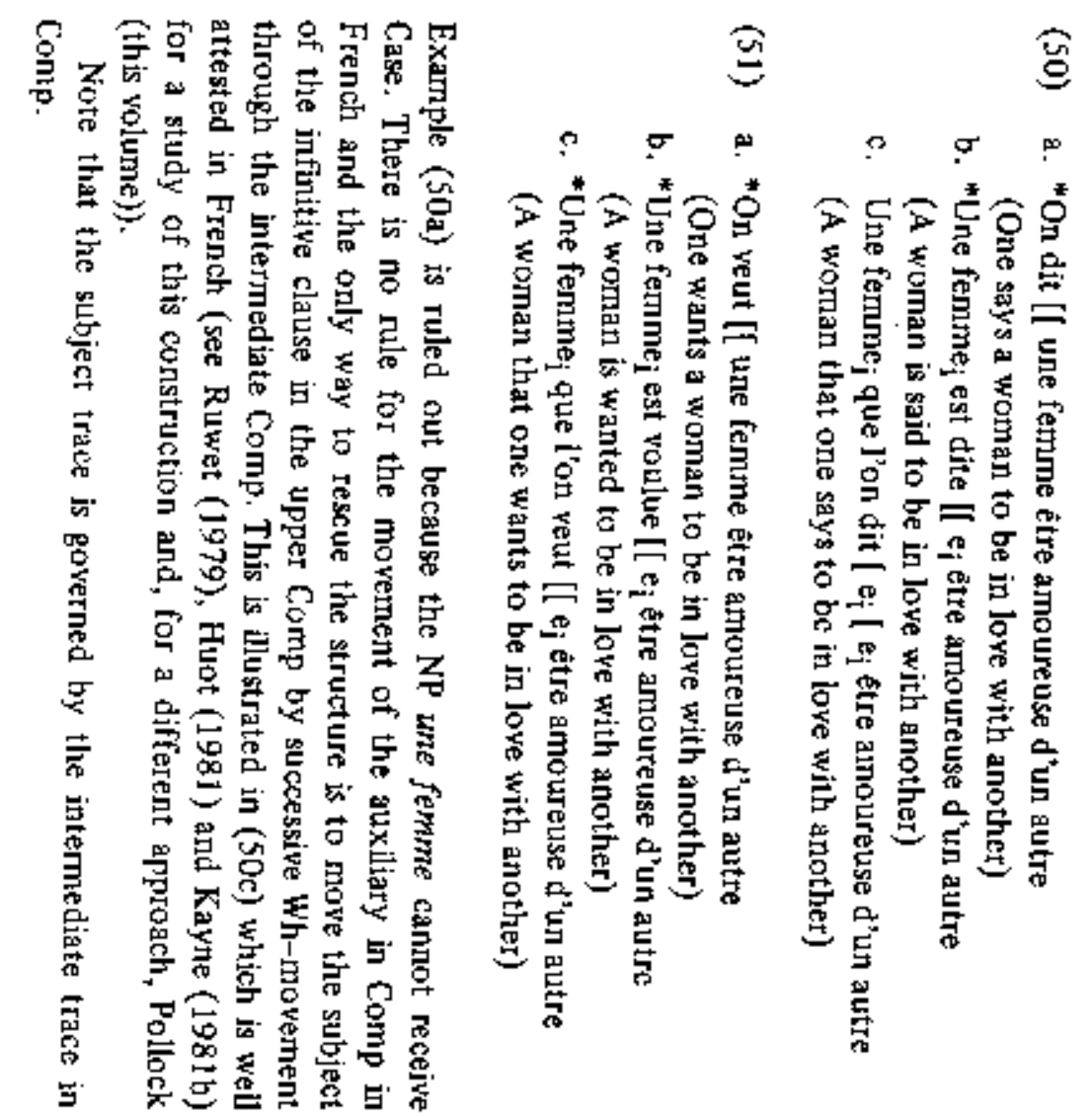

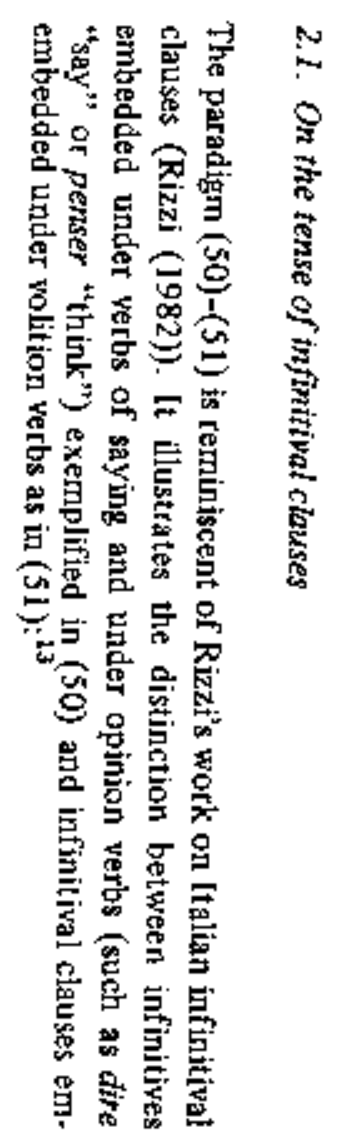

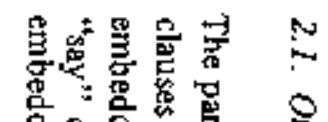

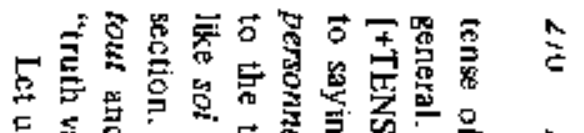

홍으.

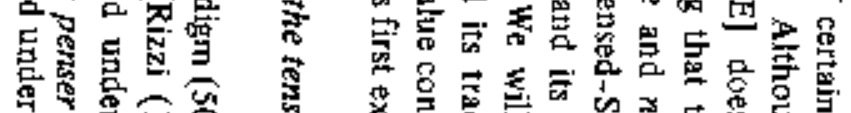

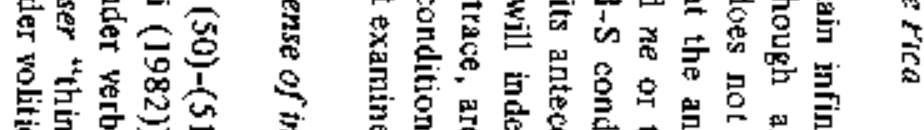

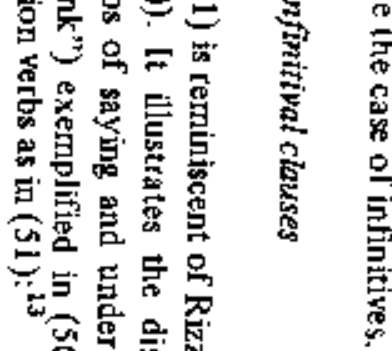

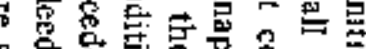
맘

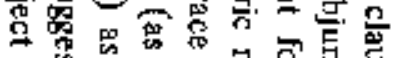
o

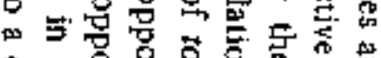

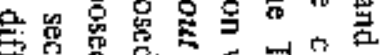

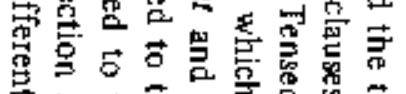

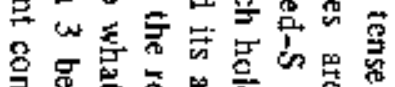

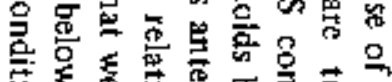

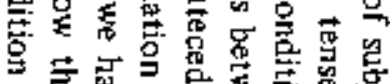

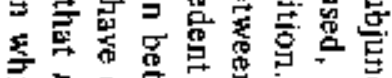

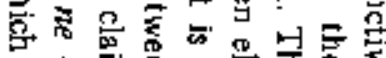

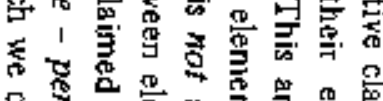

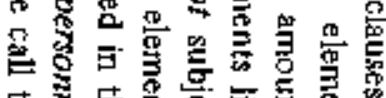

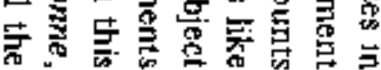

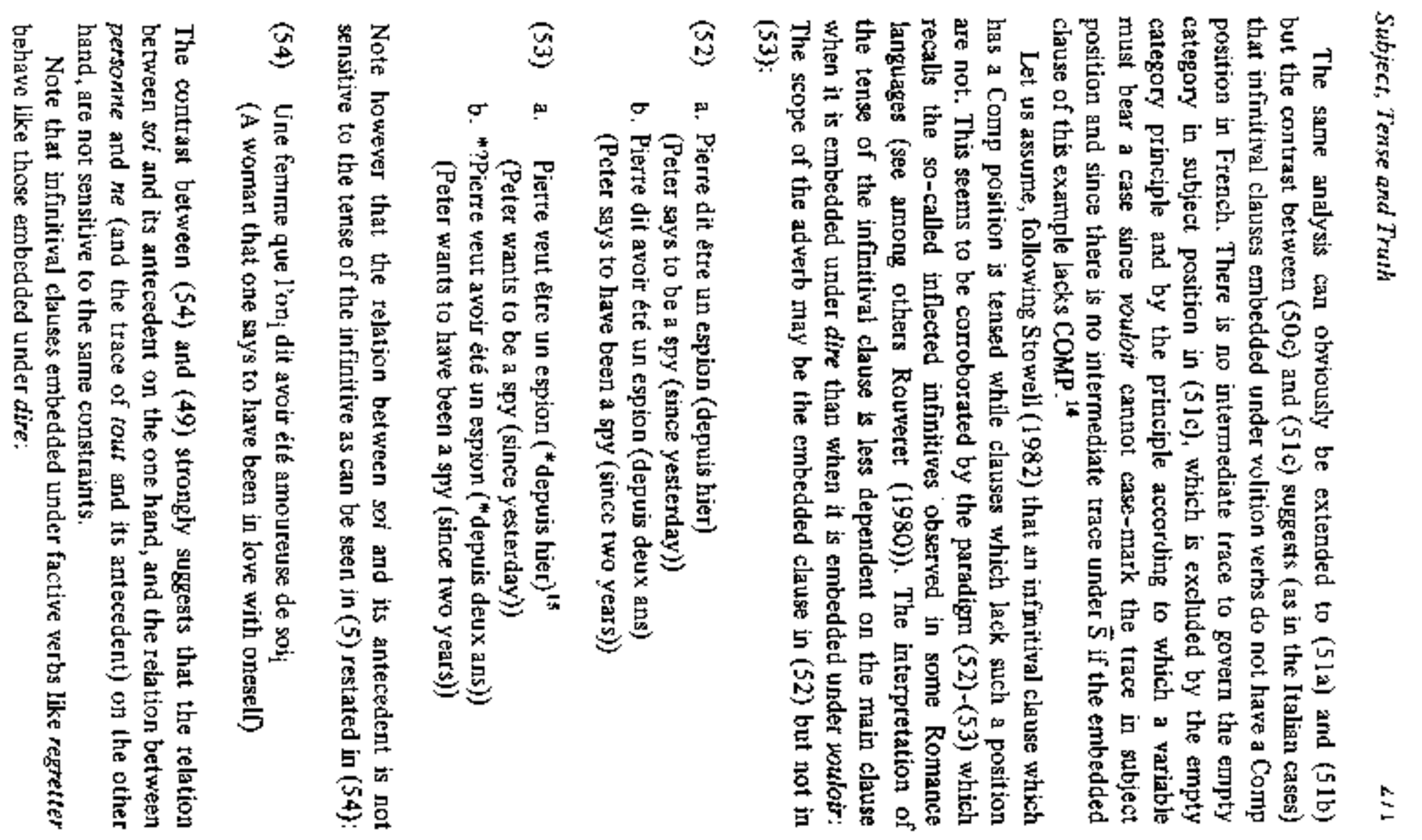




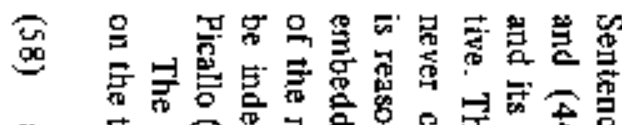

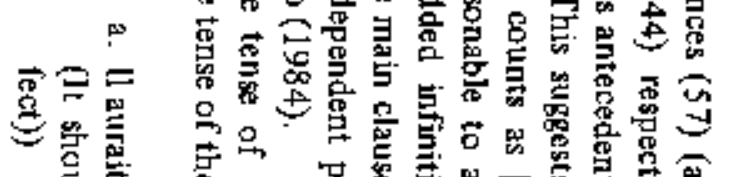

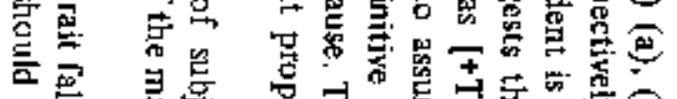

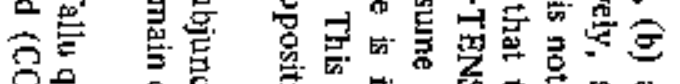

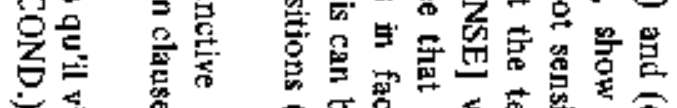

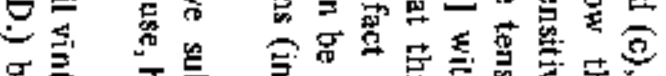

呂

㩊

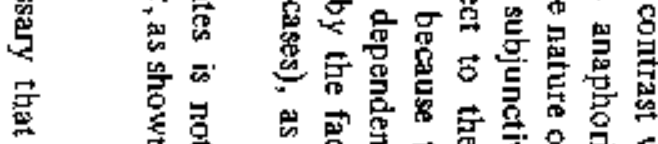

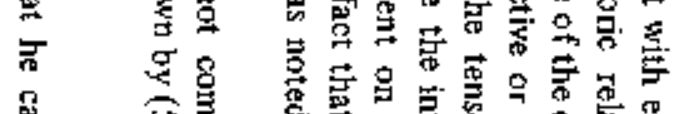

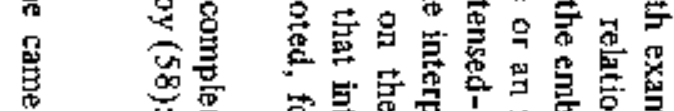

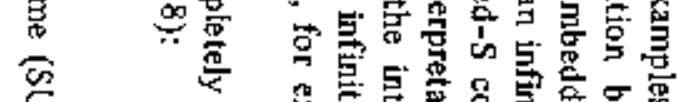

可

期

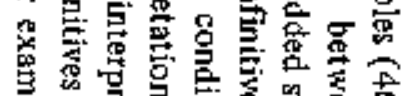

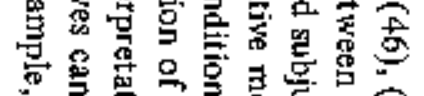

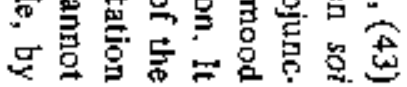

s

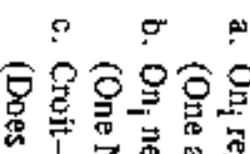

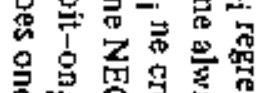

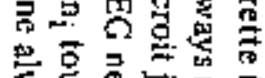

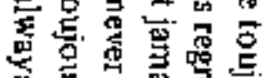

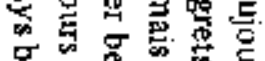

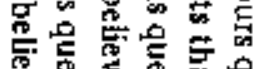

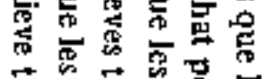

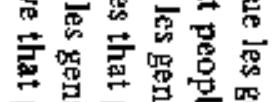

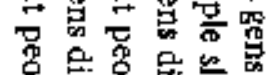

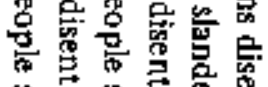

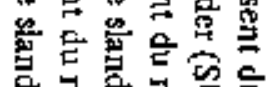

言总产突它志

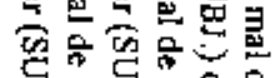

象急密总官

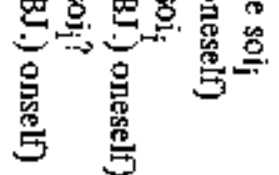

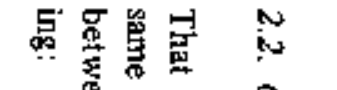

吉

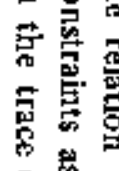

虽志罢

密密密

苦总

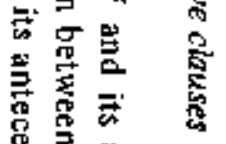

管

究 突

点学

密藏

总䯧

牙号

完 官贾

包蓉点

宾害孚
㐘 5 品 굼

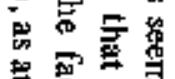

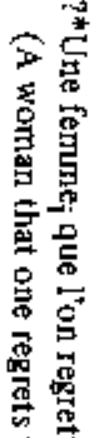

$\overrightarrow{8}$

要

要㚜

究高

点皆

莺密

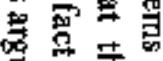

密营完

息总

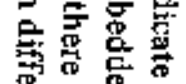

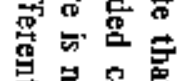

悬点魚

祭言究家

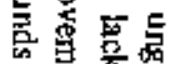
匜曋否骂

요용

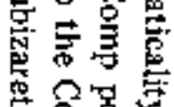

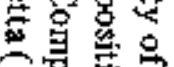

它要要

总 5

客司完

吅哭

安 공

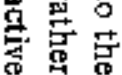

药 N

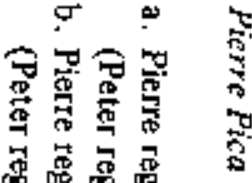

量重

क

氙号

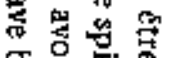

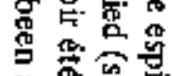

营䨐苟

氙

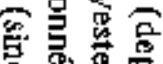

豆言

嵒㤐要

蓦焉

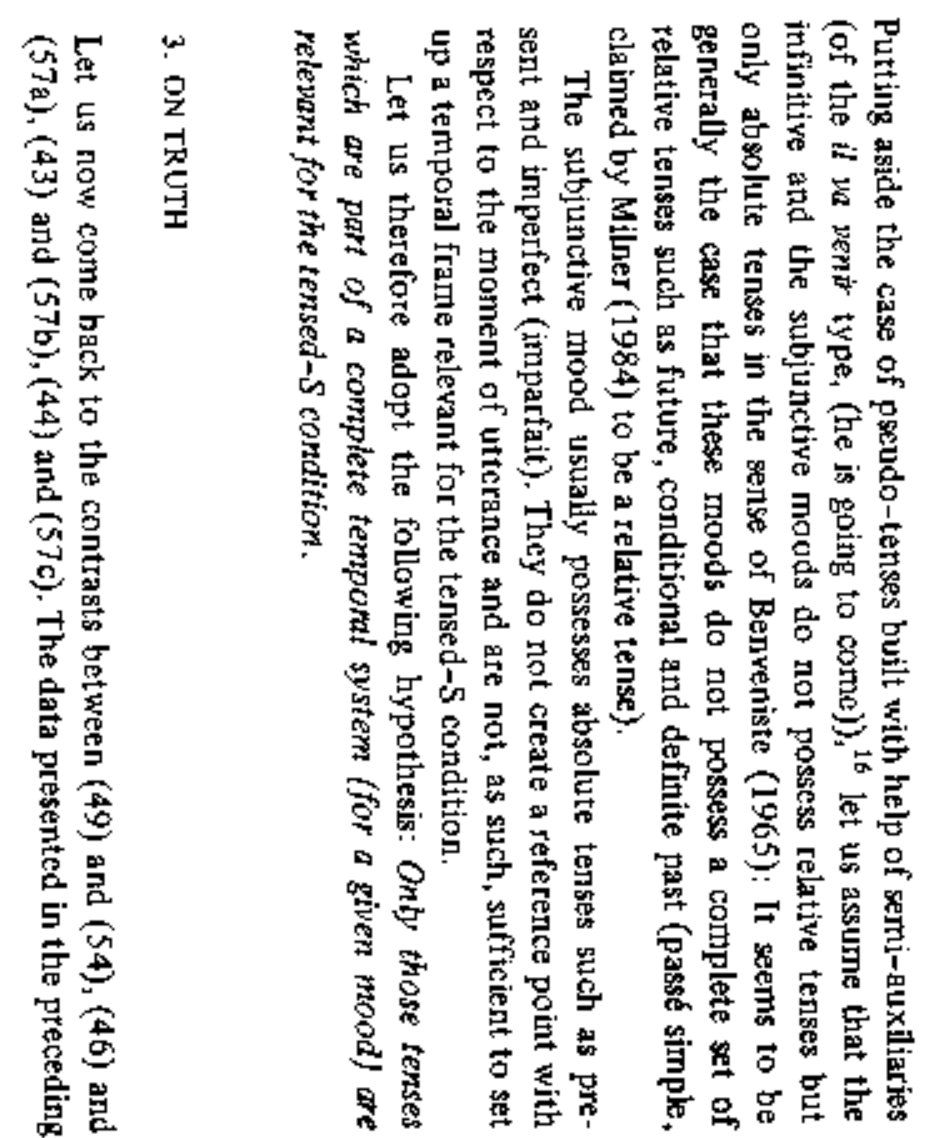

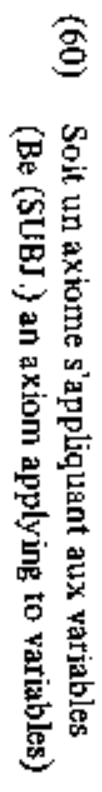

号兽

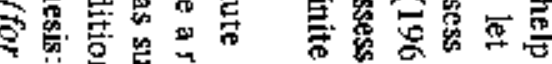

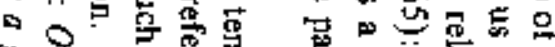

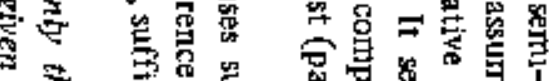

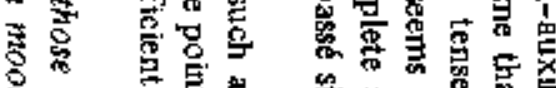

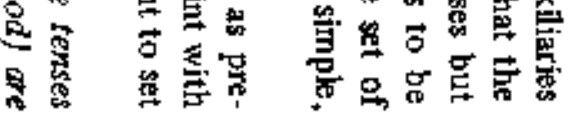

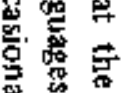

(⿻日禸

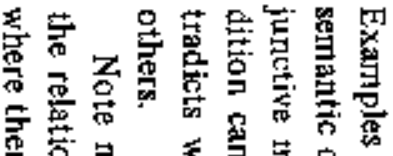

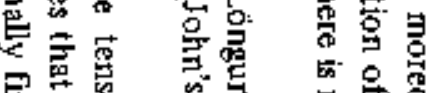

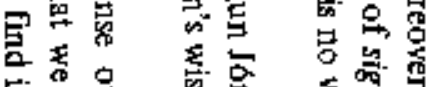

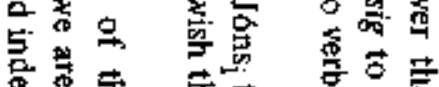

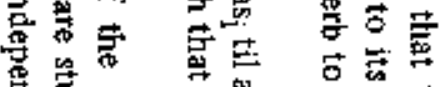

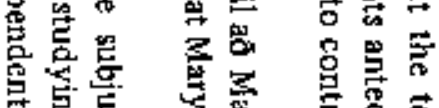

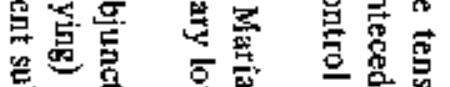

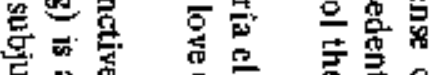

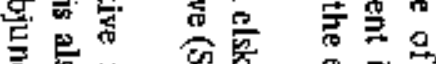

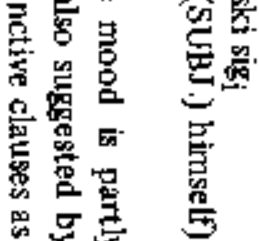

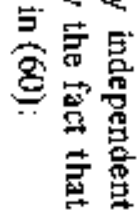

总

票寄

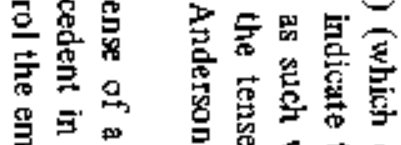

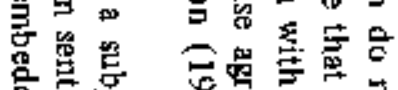

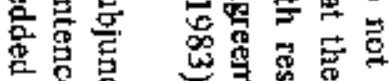

台

衷器

喜帮

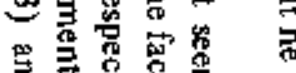

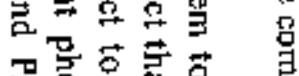

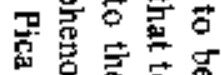
क्

当

是

焉

言

\%

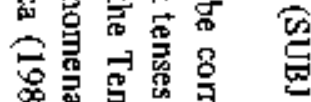

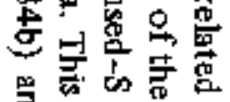

就总。 $\rightarrow$ 点点吉

荅客

要

多完它

甼察

究

量 


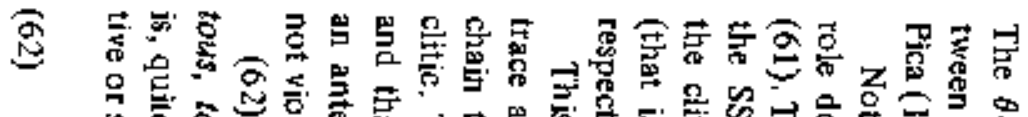
品

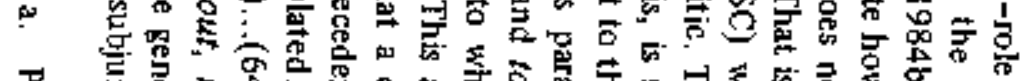
要要

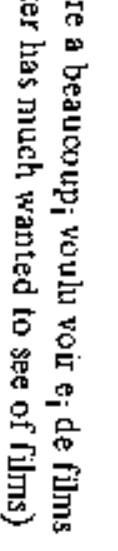

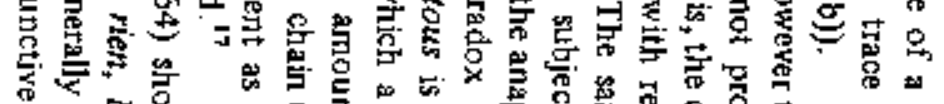

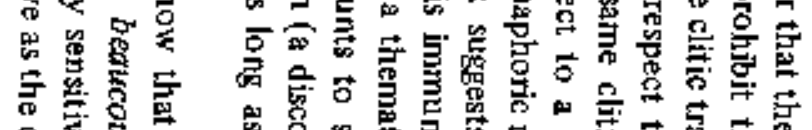

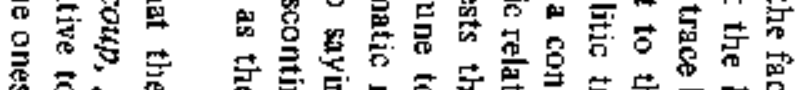

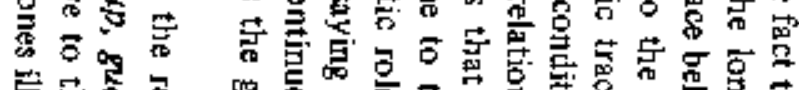

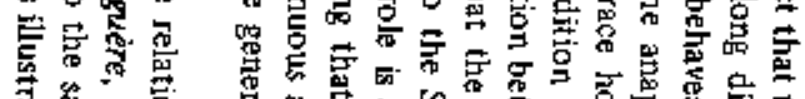

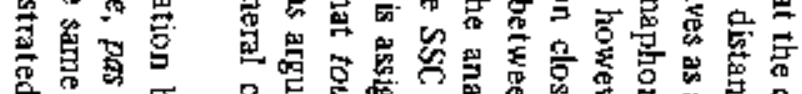
2.

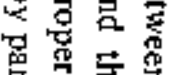
密密家

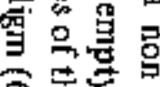
要

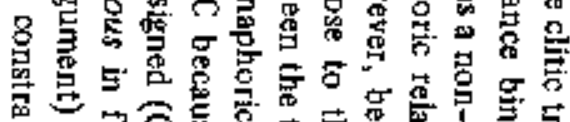

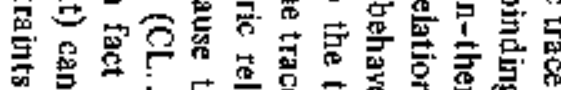

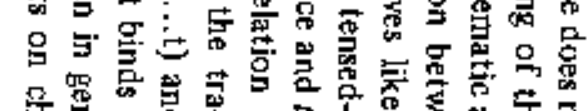

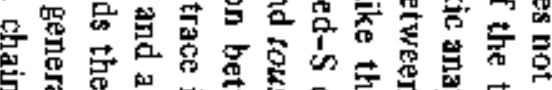
界

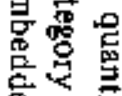

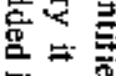

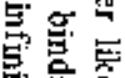

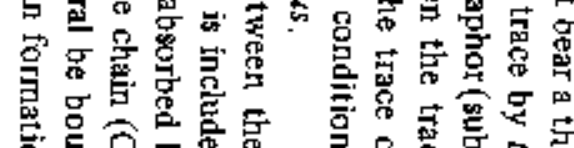

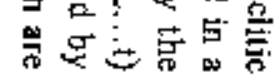

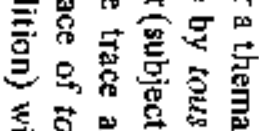

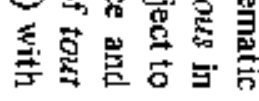

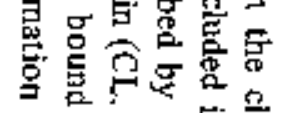

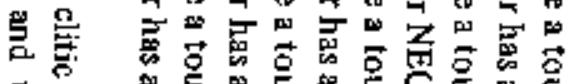

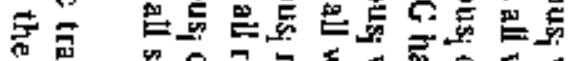

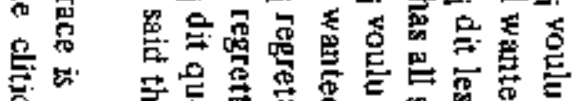

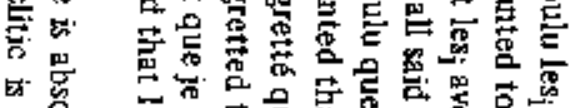
E.

을 空

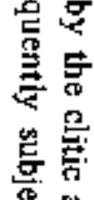
产. 官 空 密要

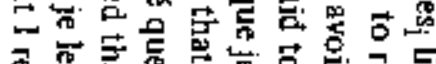

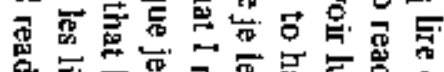

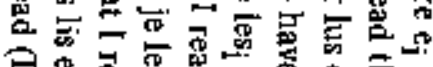

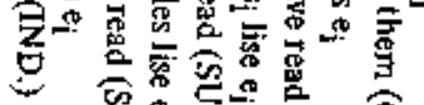

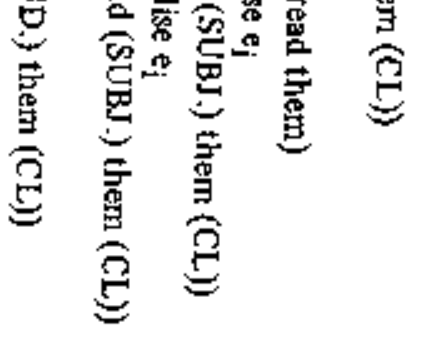

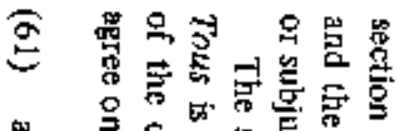

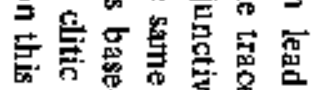

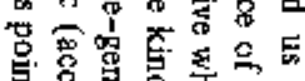

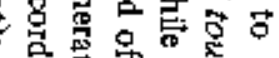

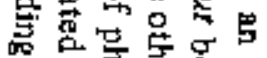

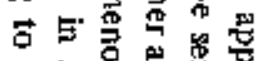

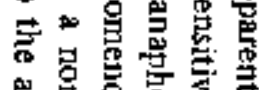

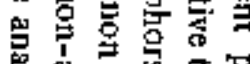

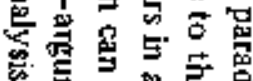

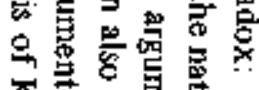

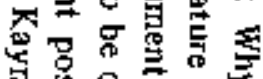
굴을

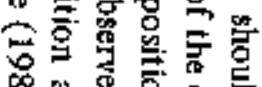
范范可司

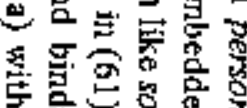

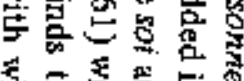

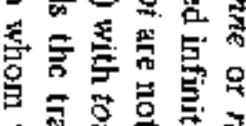

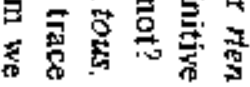

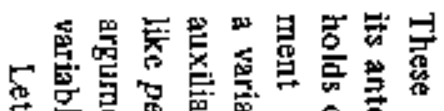

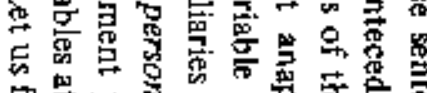

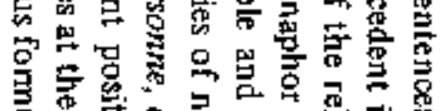

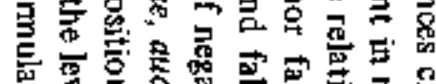

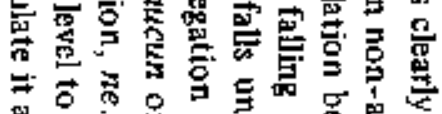

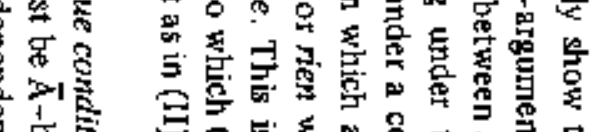

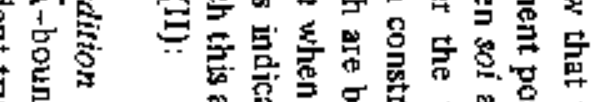

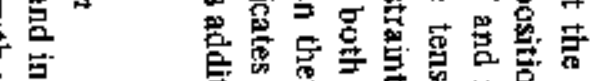

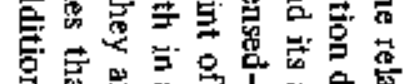

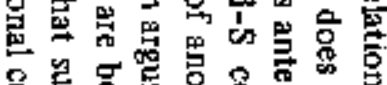

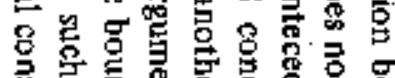

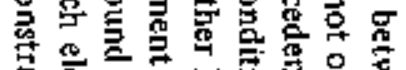

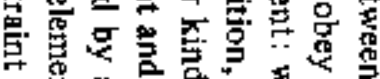

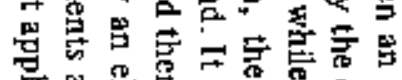

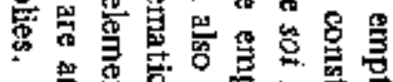
要要

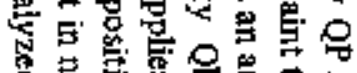

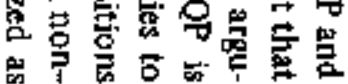

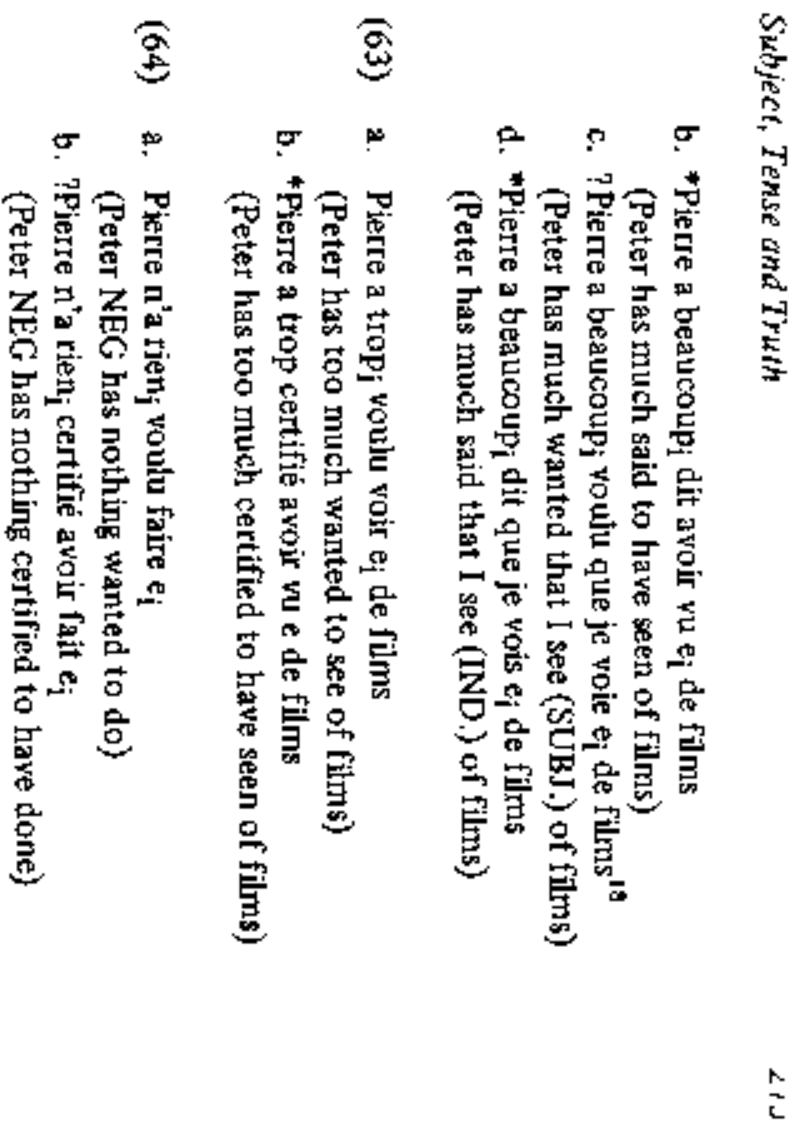




\begin{tabular}{|c|c|c|c|c|c|c|c|c|}
\hline 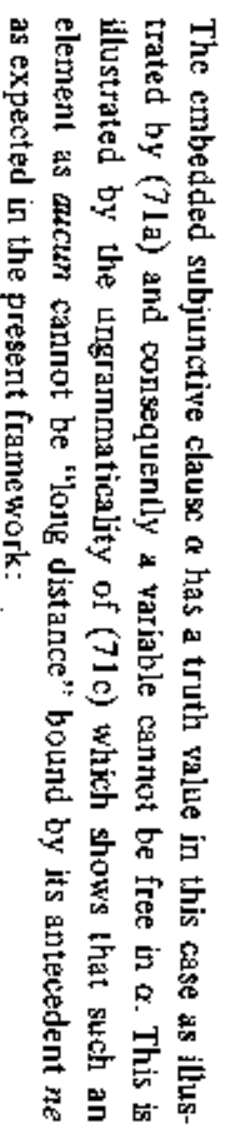 & 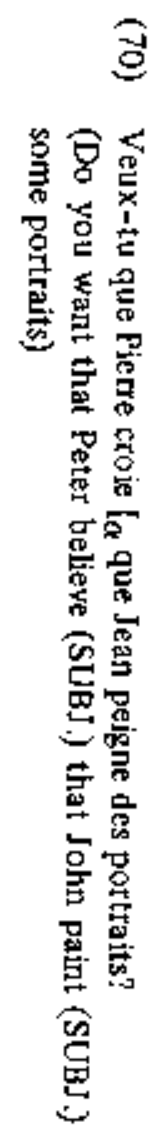 & 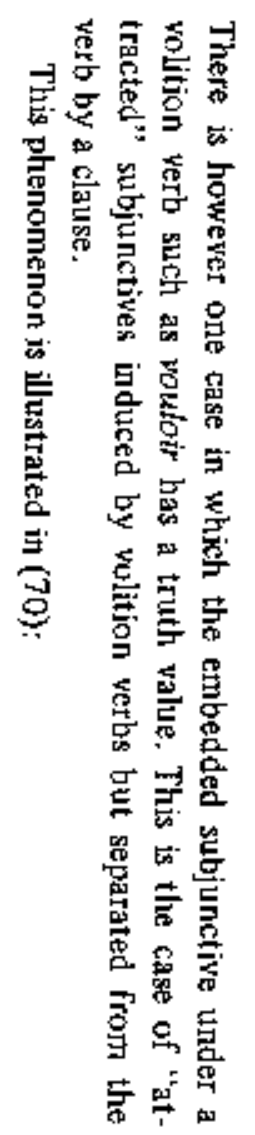 & 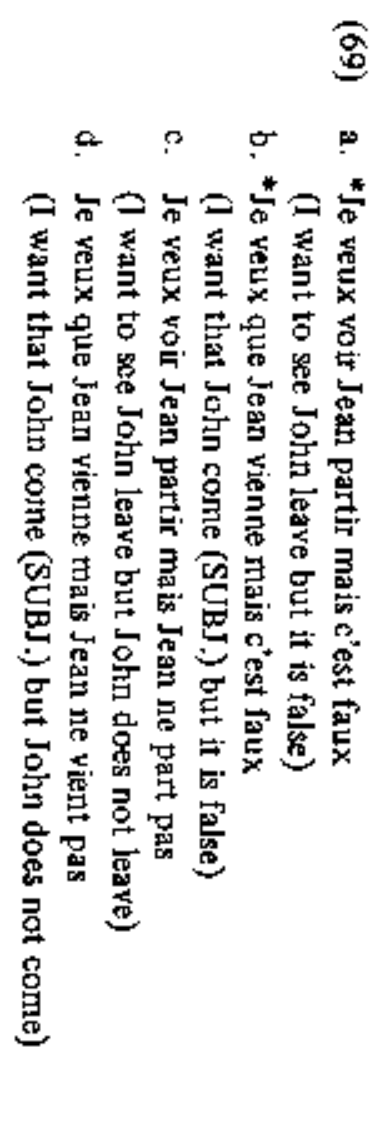 & 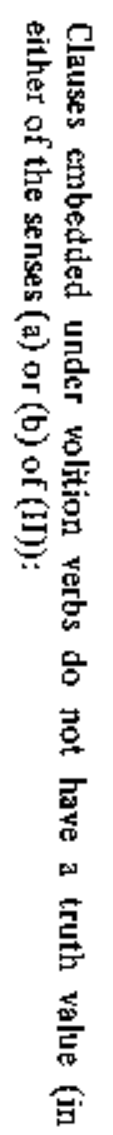 & 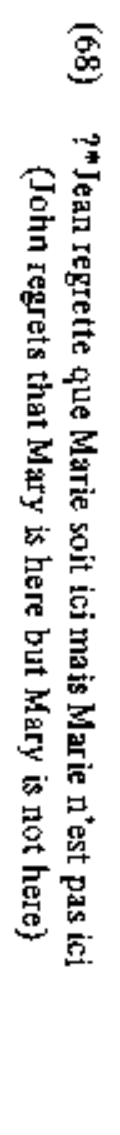 & 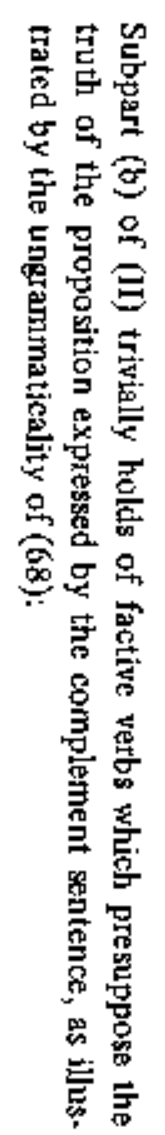 & 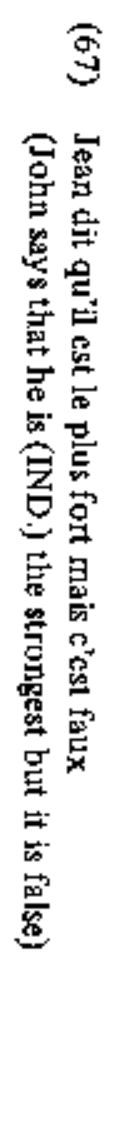 & 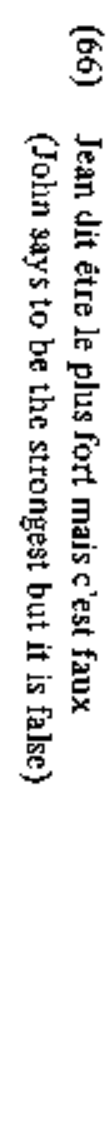 \\
\hline
\end{tabular}

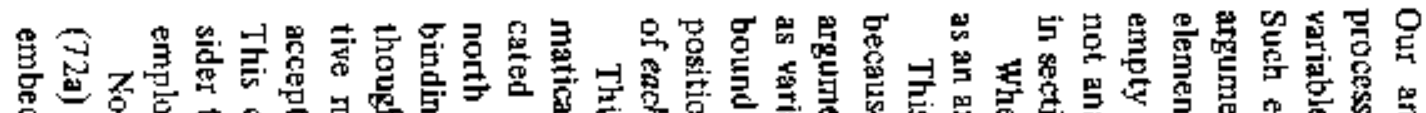

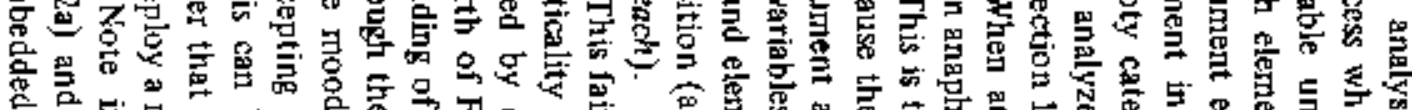

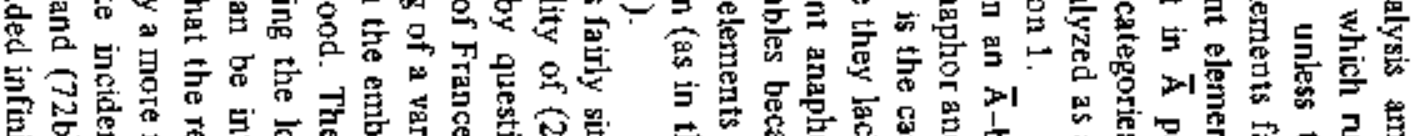

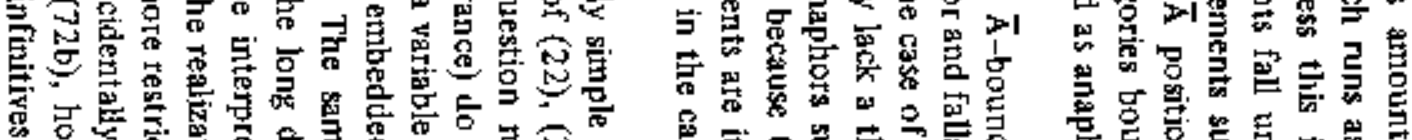

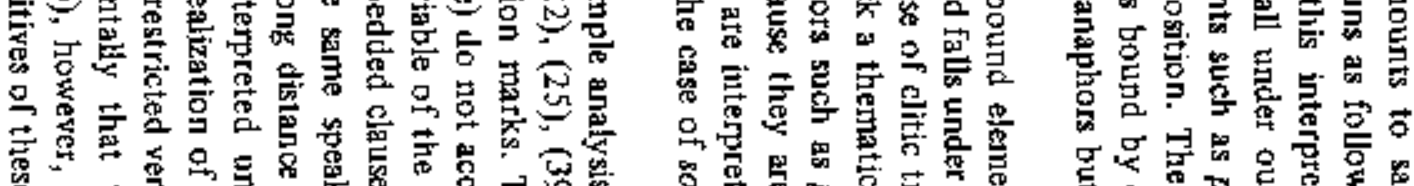

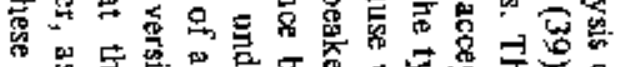

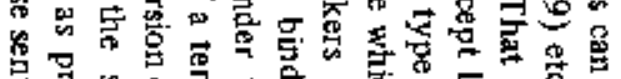

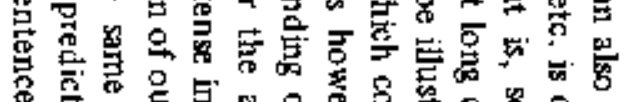

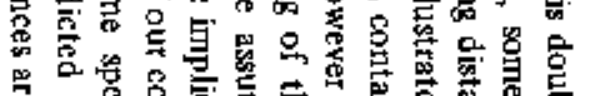

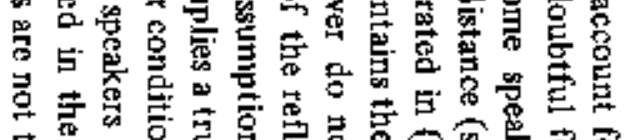

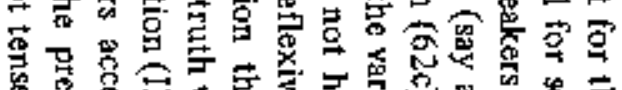

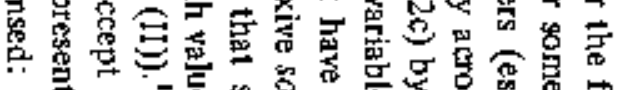

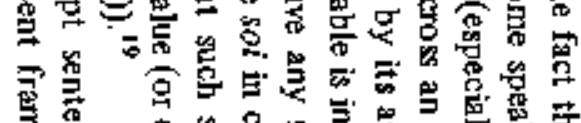

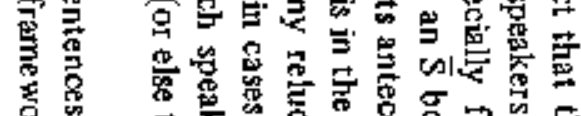

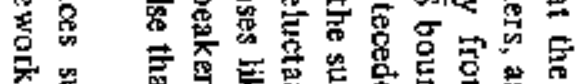

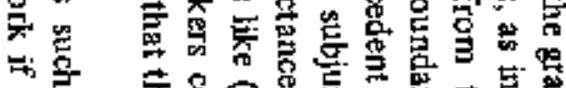

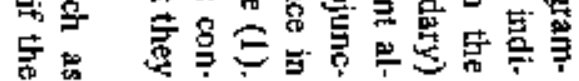

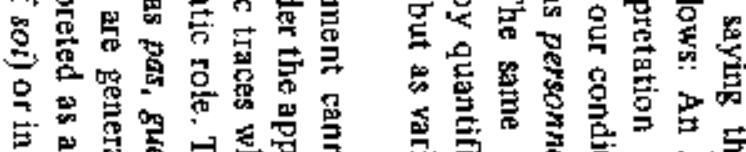

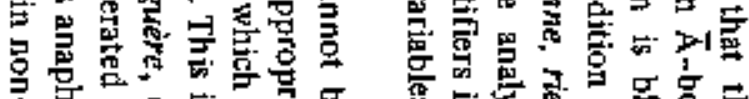

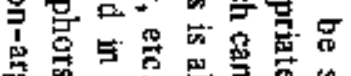

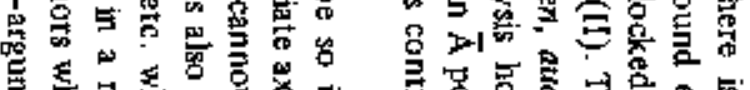

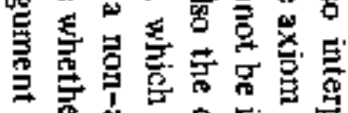

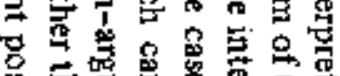

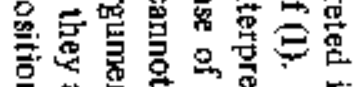

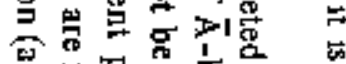

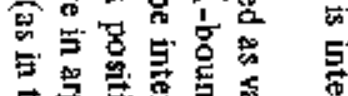

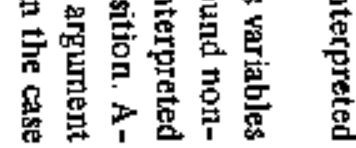

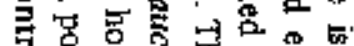

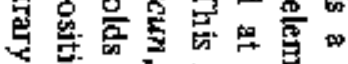

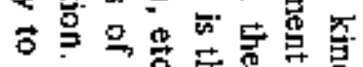

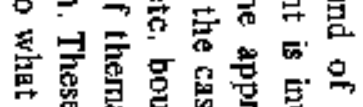

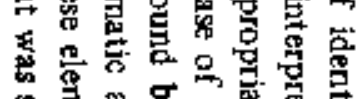

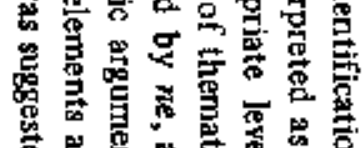

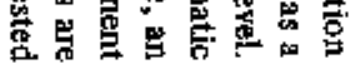

$\Xi$<smiles>[CH]1C=CC1</smiles>

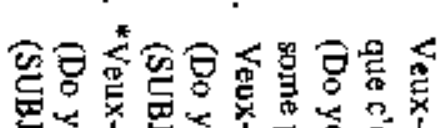

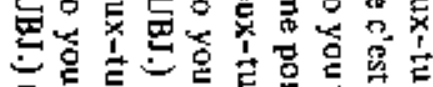

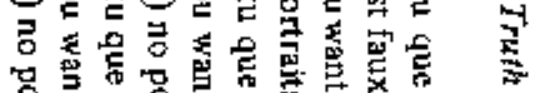

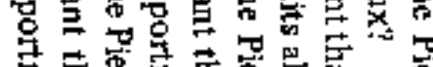

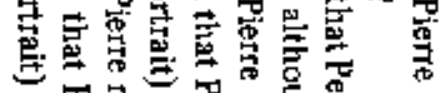

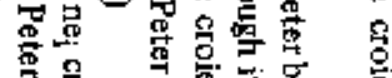

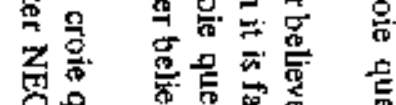

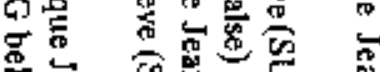

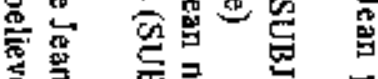

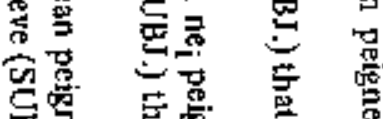

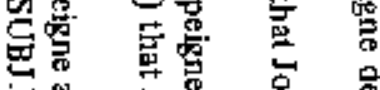

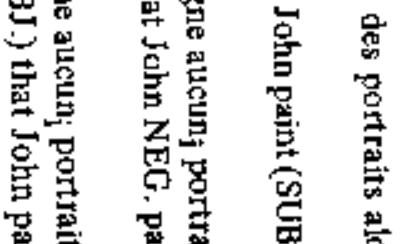

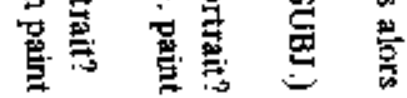




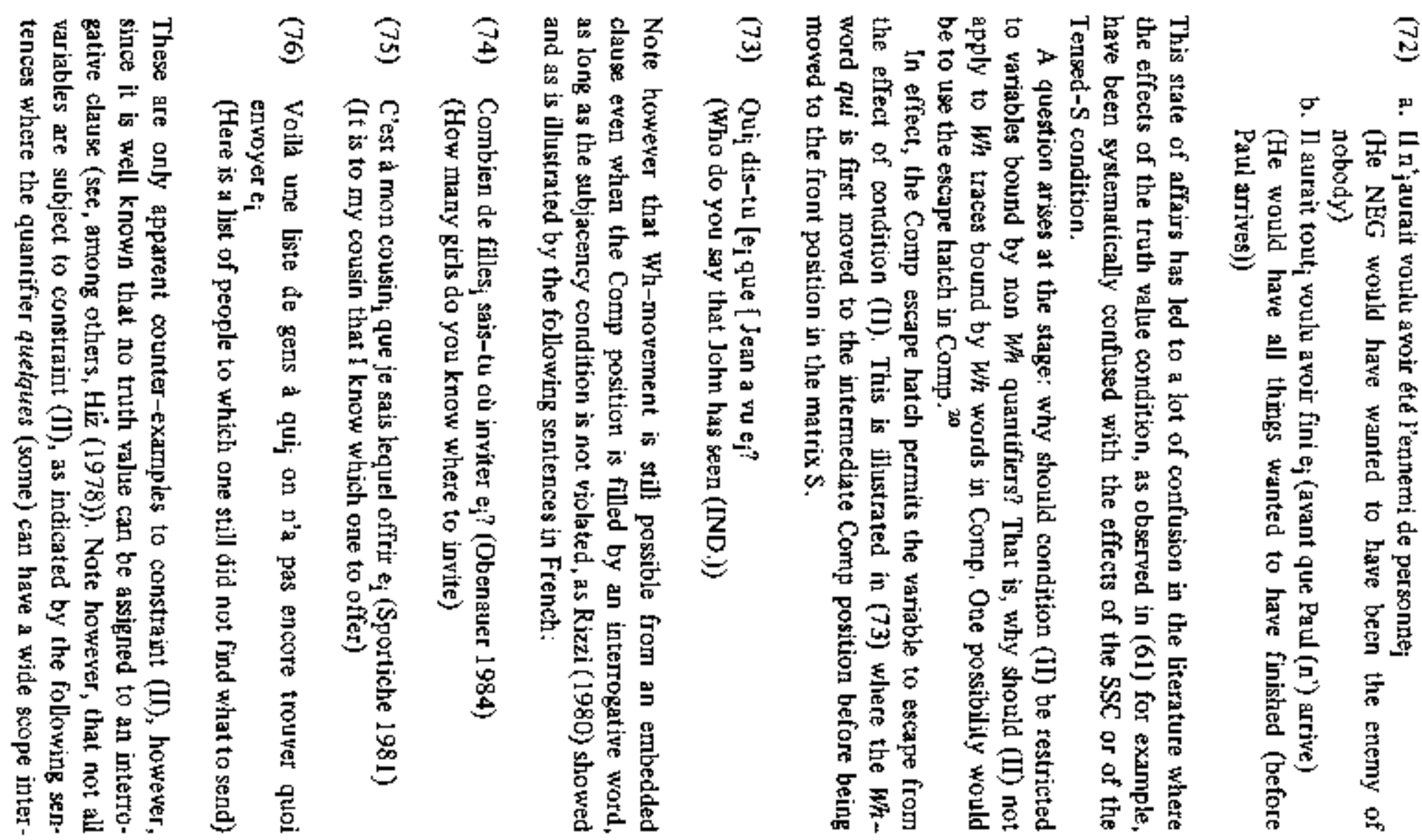

$\stackrel{N}{\mathbb{J}}$

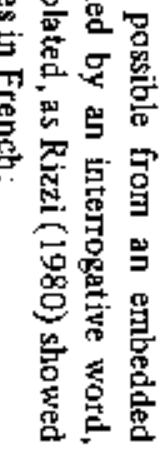

$\frac{8}{3}$

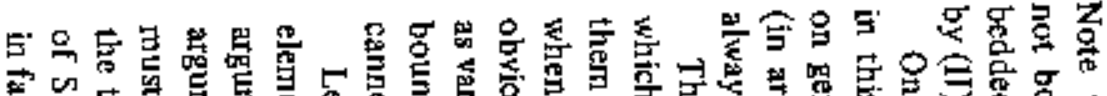

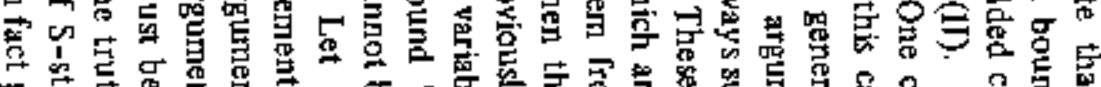

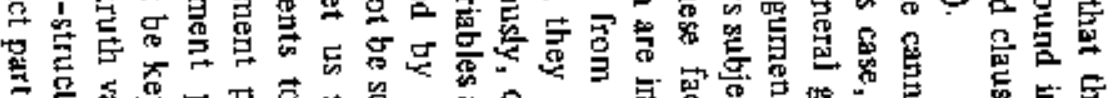

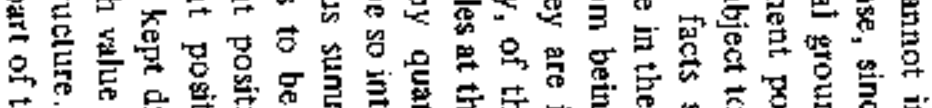

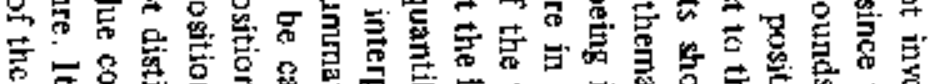

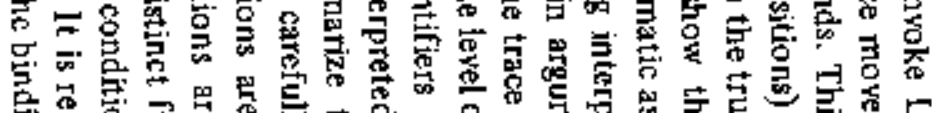

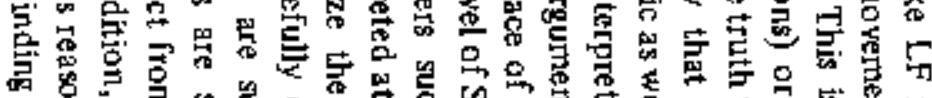

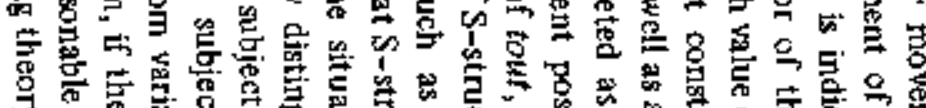

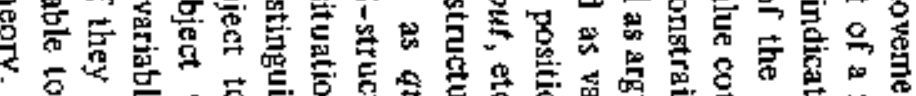

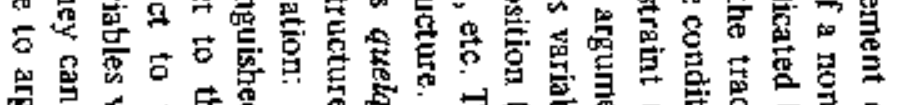

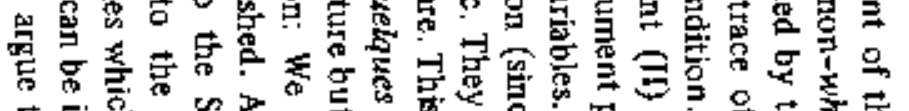

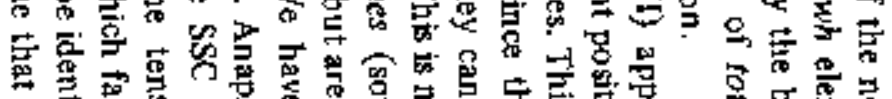

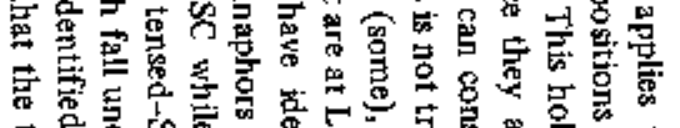

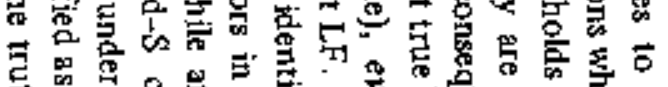

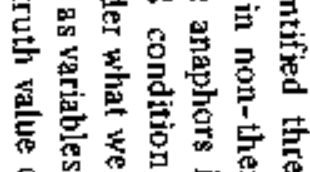

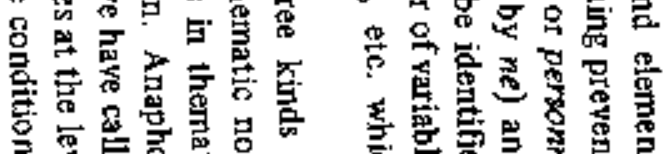

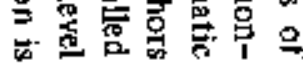

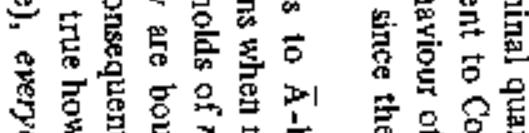

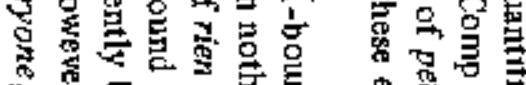

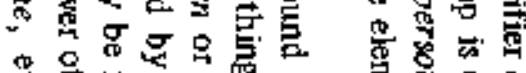

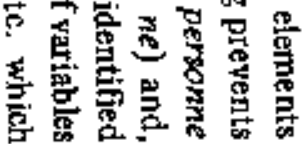

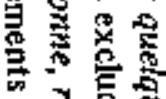

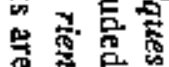

察官

을

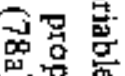

喍

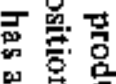

宔实兽

惡品

焉吉官

心䍐称

莺

暨

o 5

䒿豆总

兽亭

홍몽

害焉点 $\underset{\infty}{\infty}$

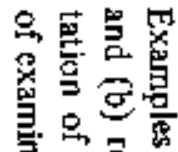

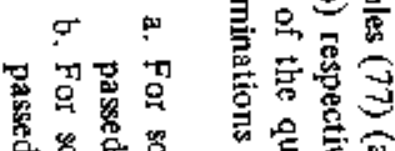

点骂

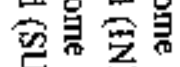

氞踏

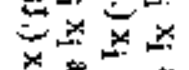

的富恶

费害

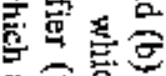

鱼喜兽

宫哭

눙용

可

壳灾密

密要空

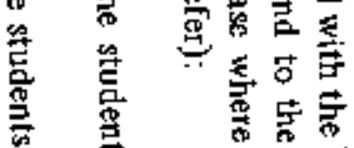

峦

营 哭

害管学

害急

站 咅

察 需

क

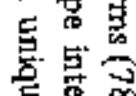

点定
3

密

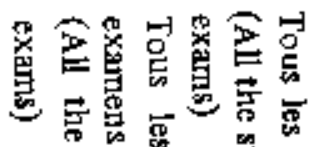

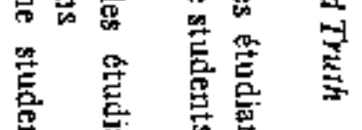

总突薄

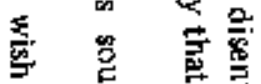

畐莺 总总

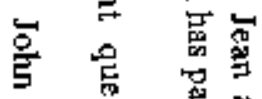

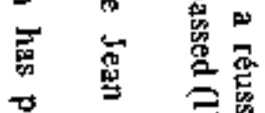

总哭 总总

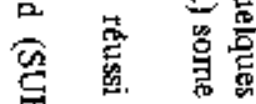

要糔 


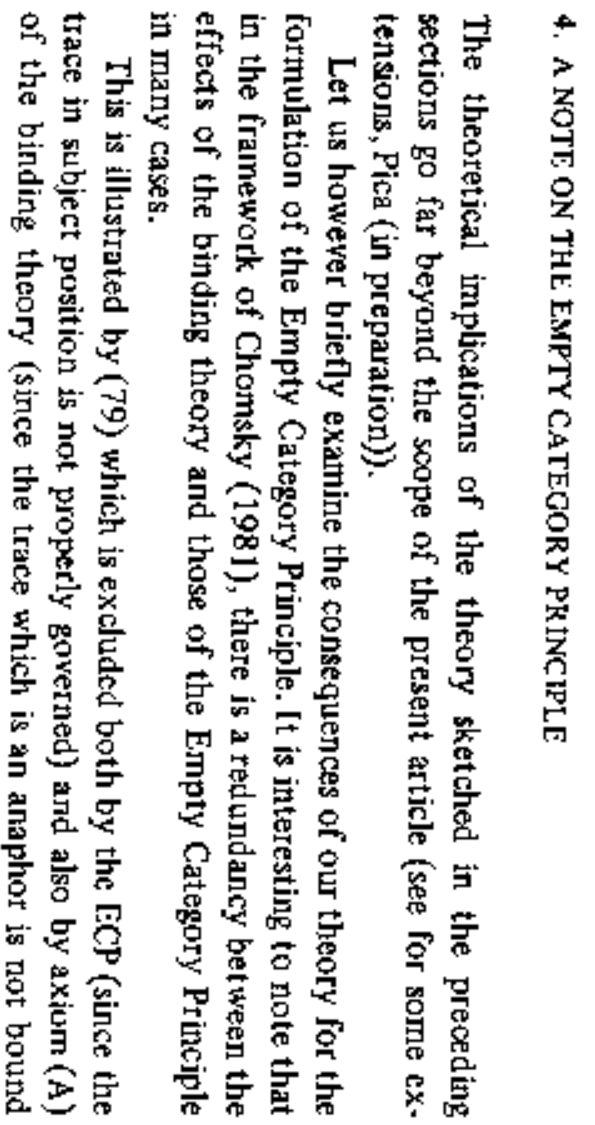

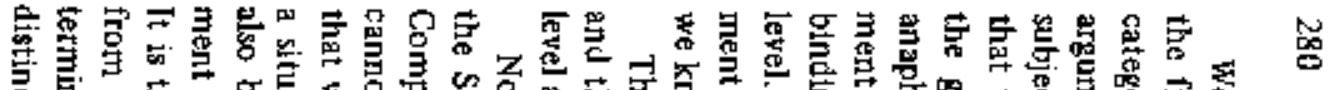

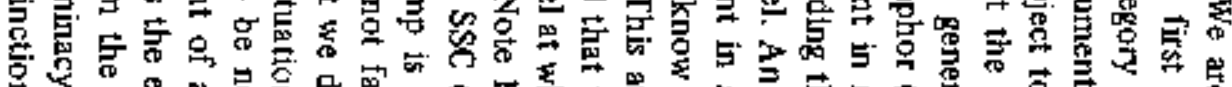

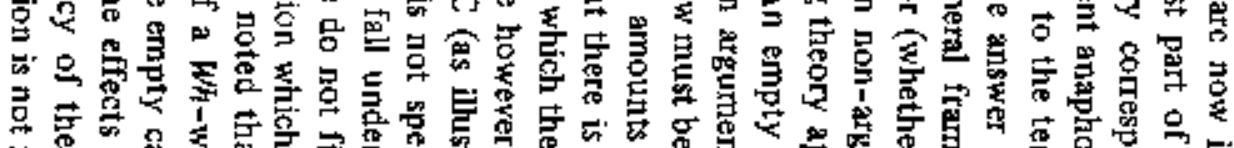

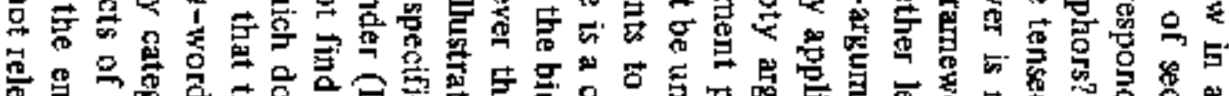

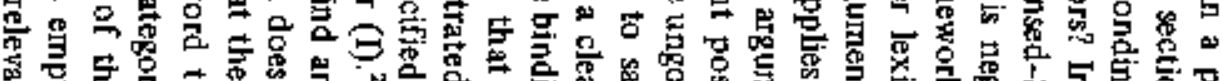

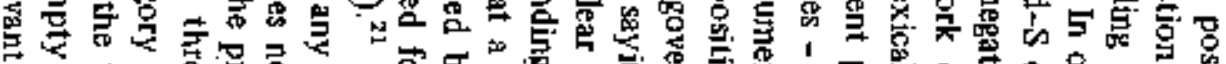

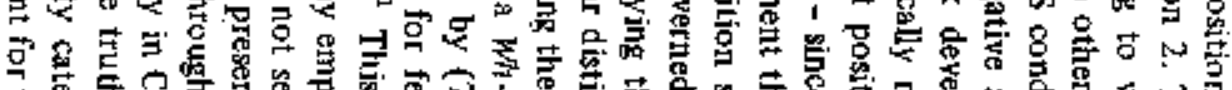

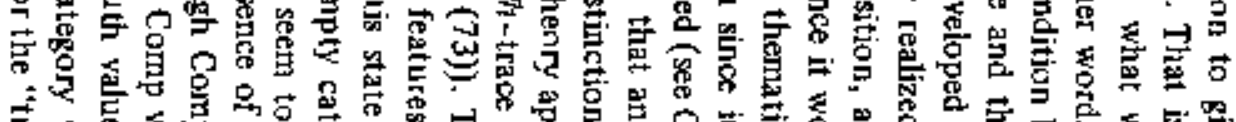

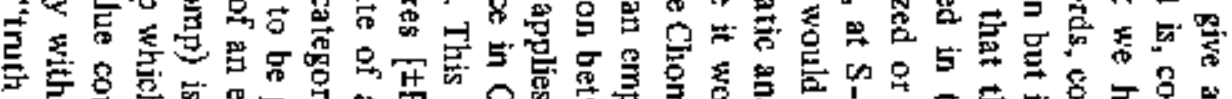

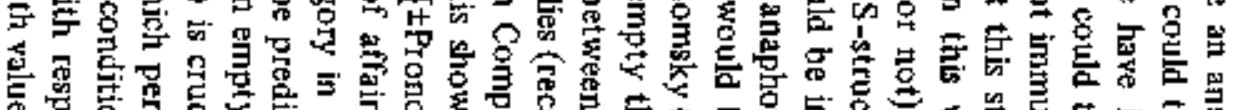

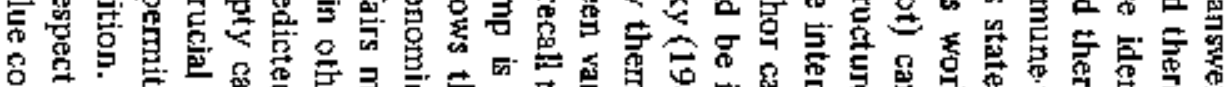

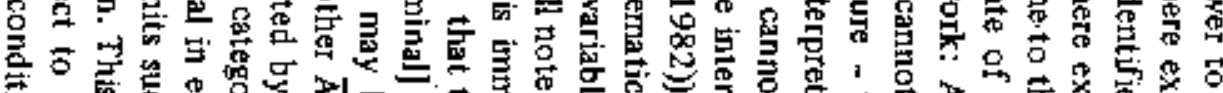

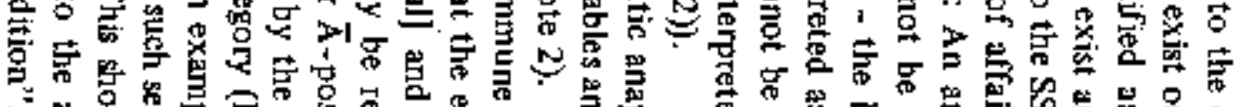

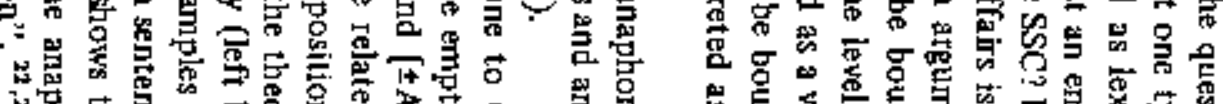

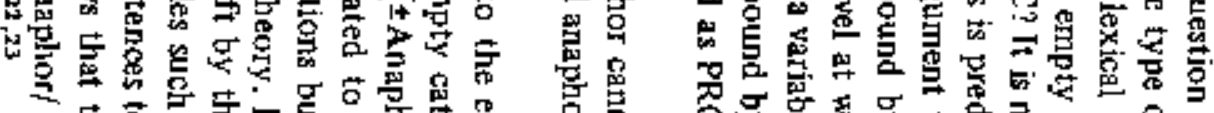

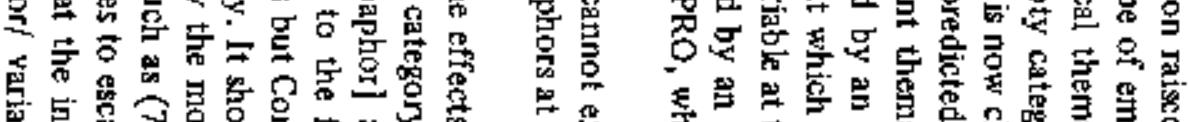

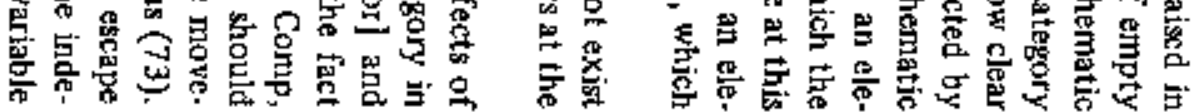

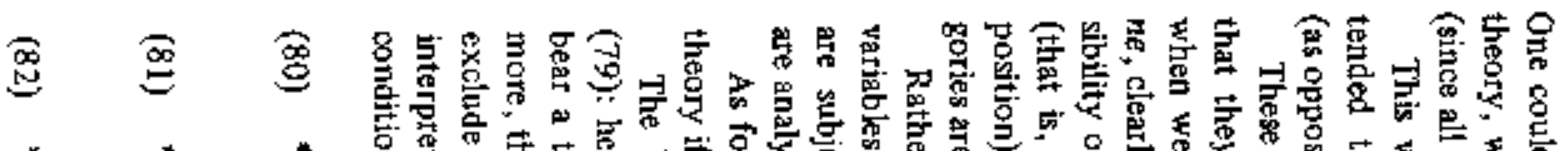

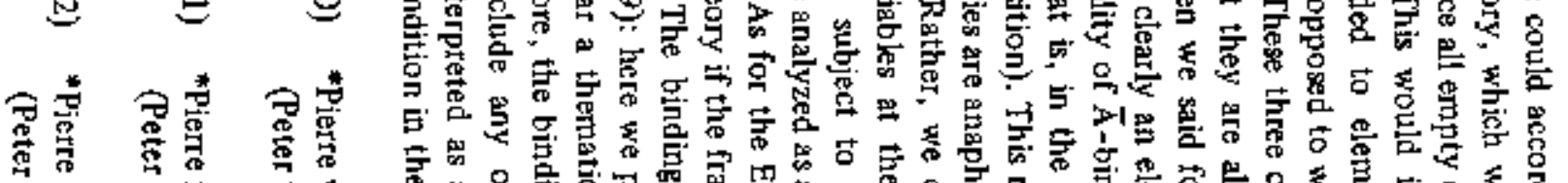

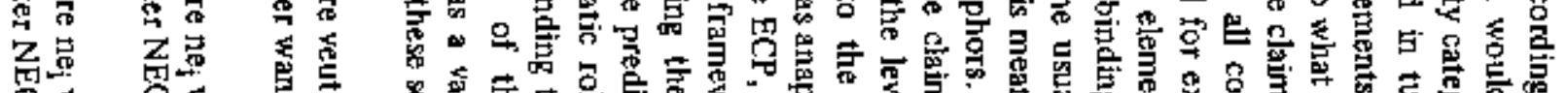

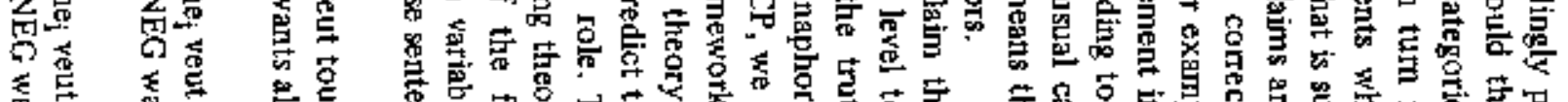

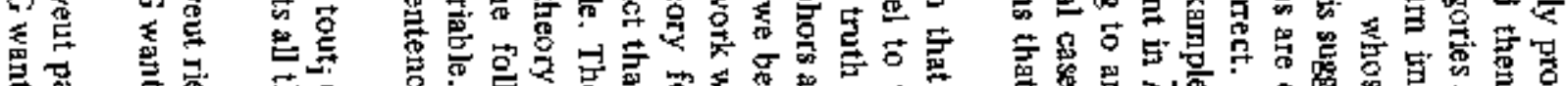

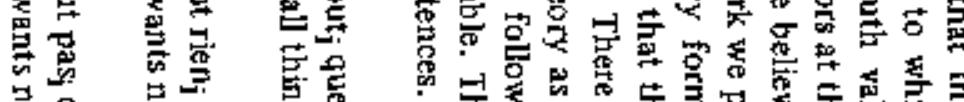

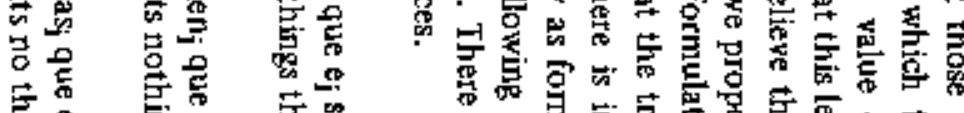

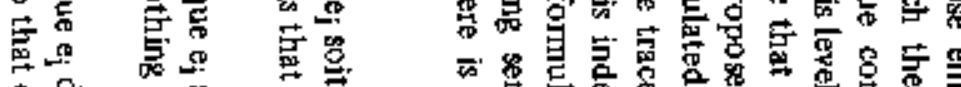

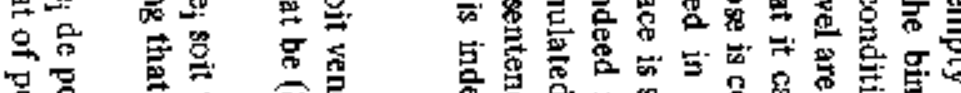

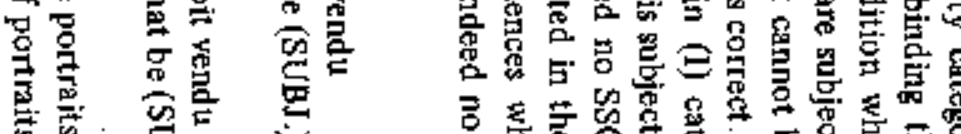

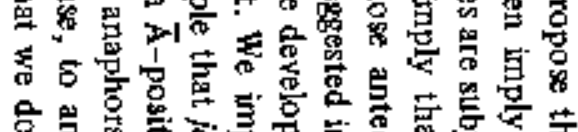

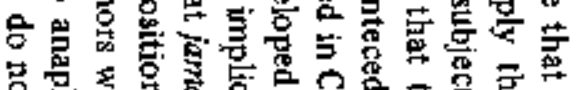

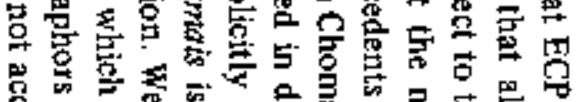

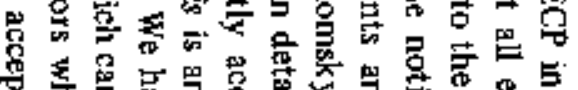

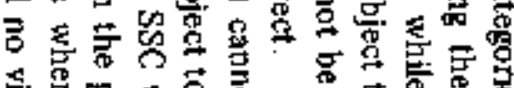

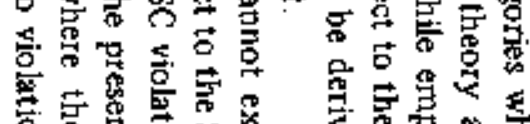

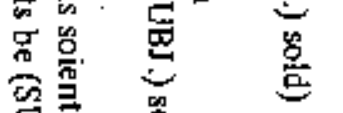

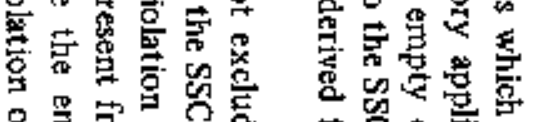

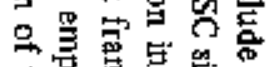

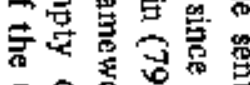

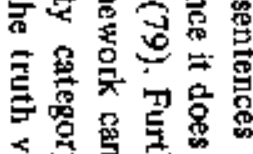

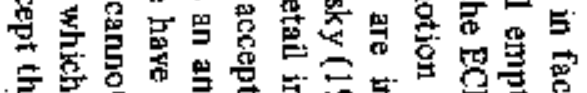

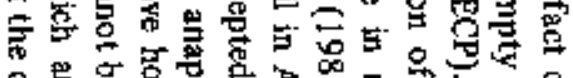

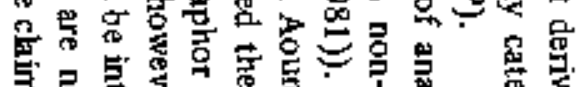

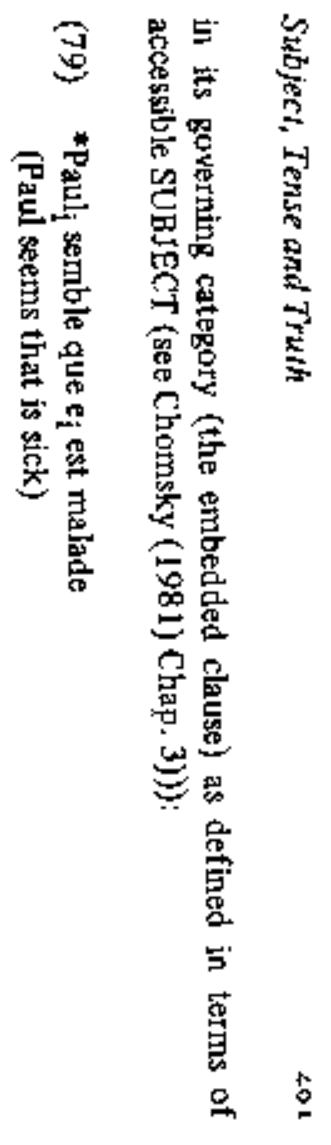




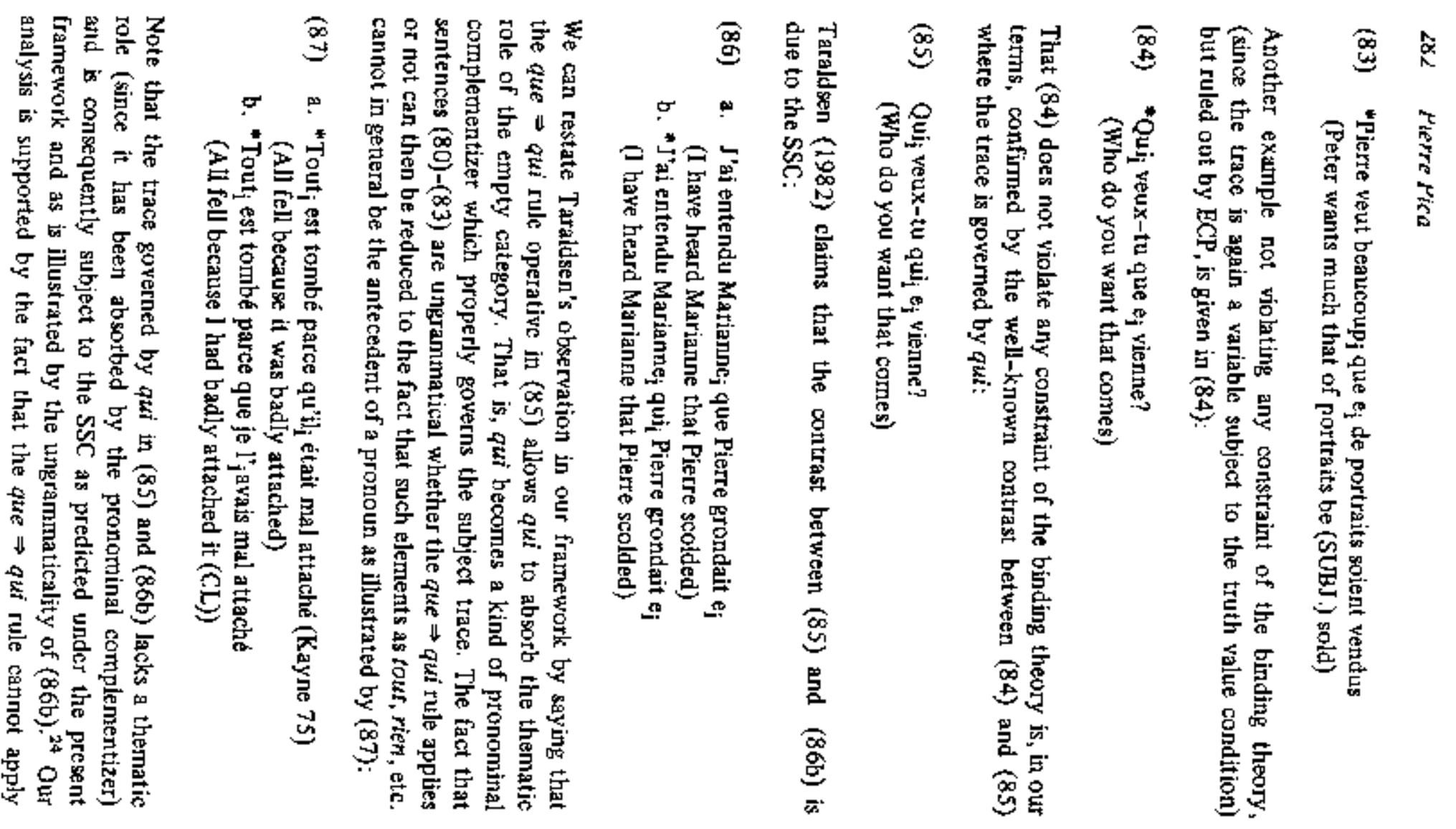

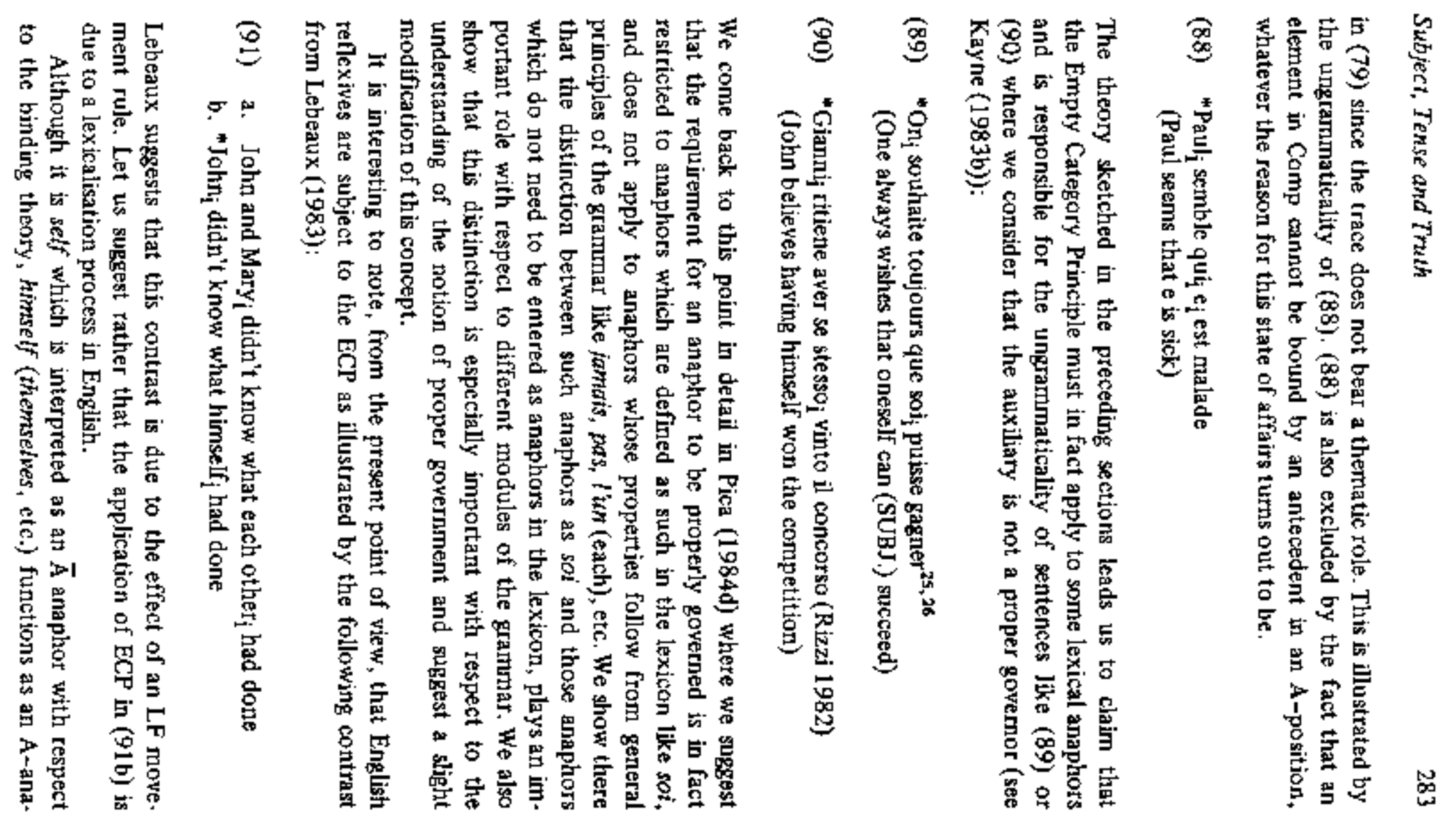




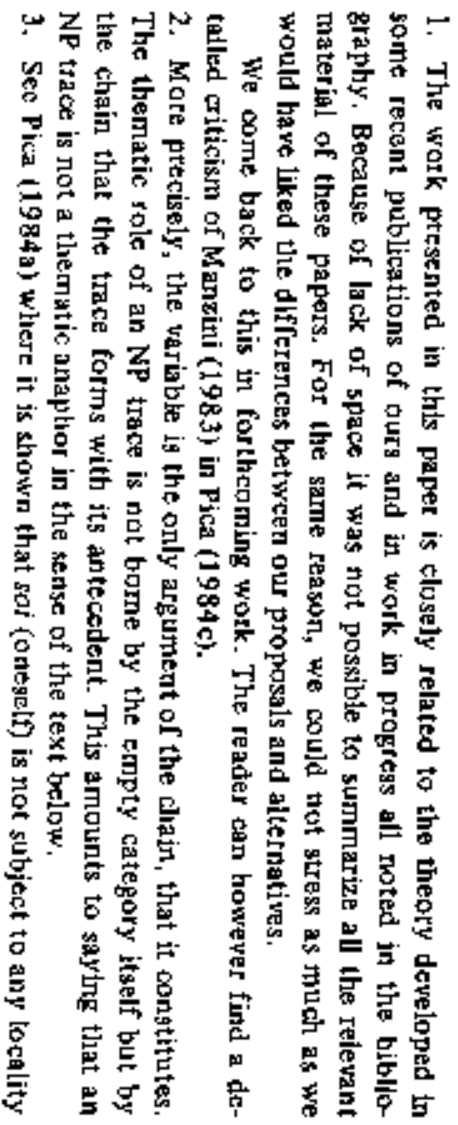

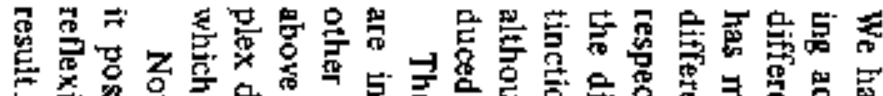

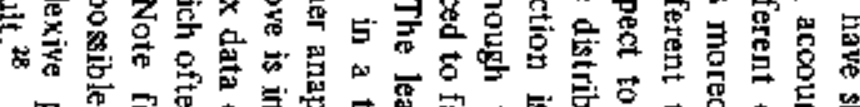

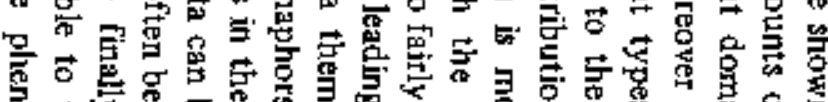

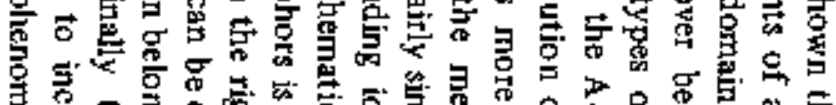

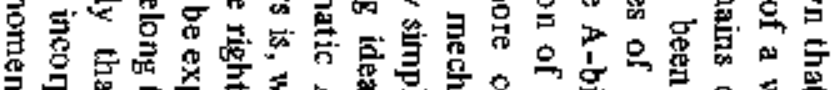

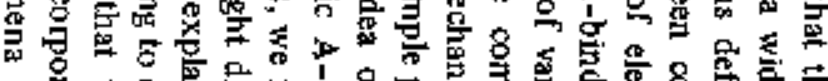

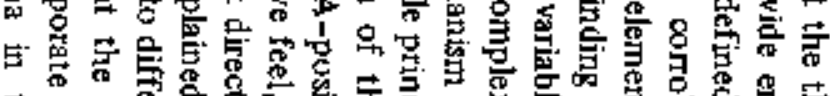

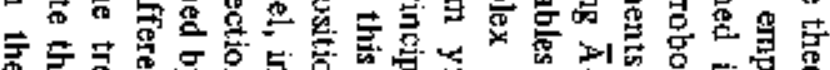
के

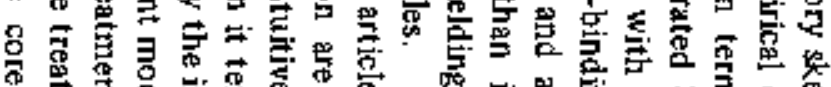
等 을

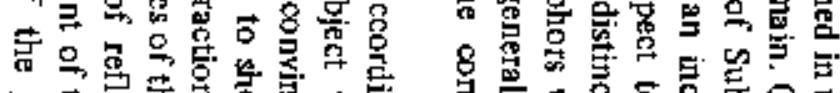

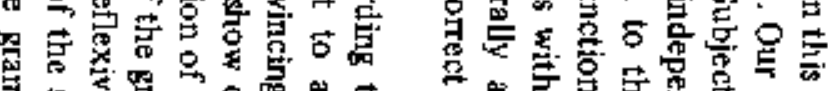

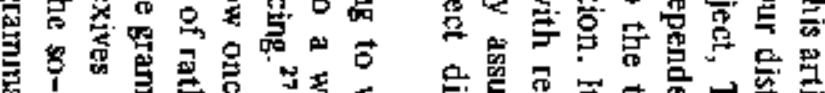

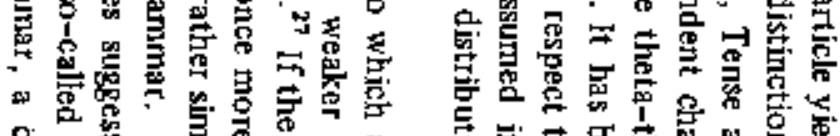

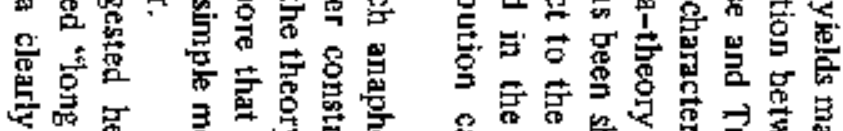

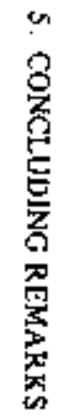

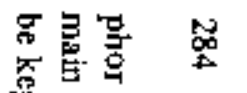

案

옹 봅 量品

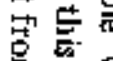
㤎空 萡 家

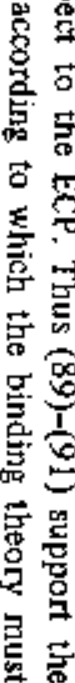

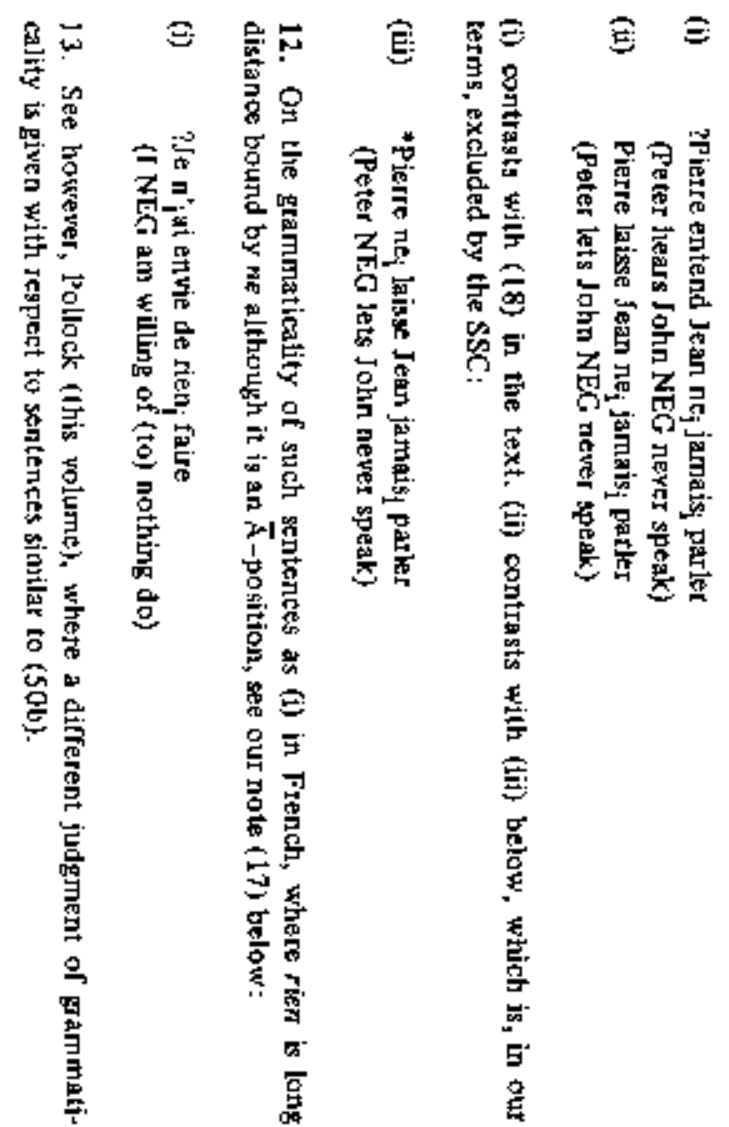

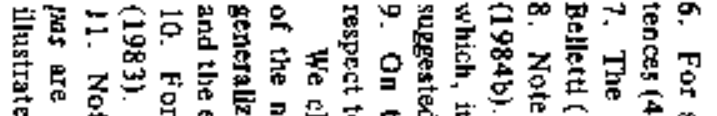

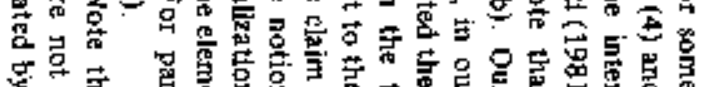

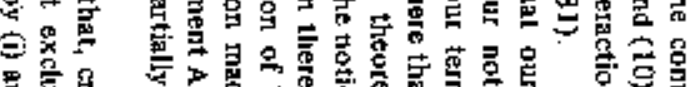

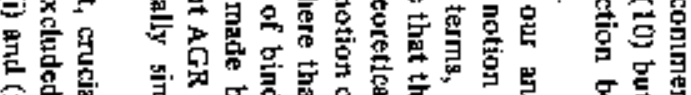

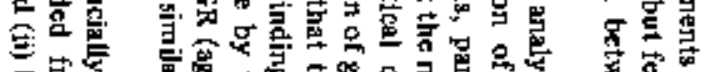

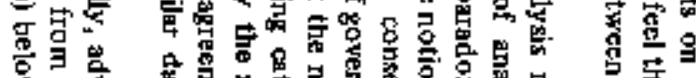

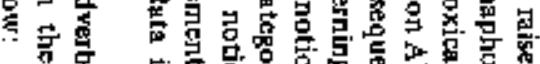

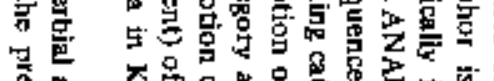

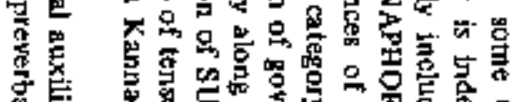

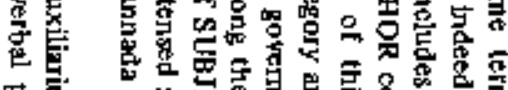

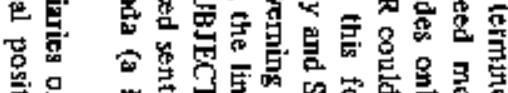

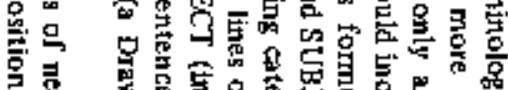

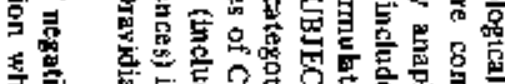

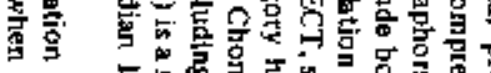

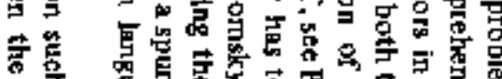

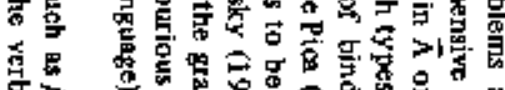

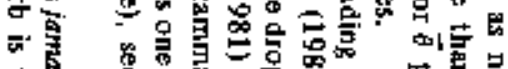
点 象

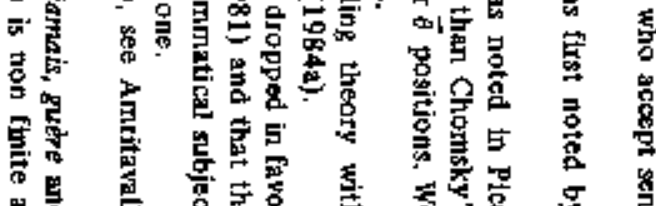

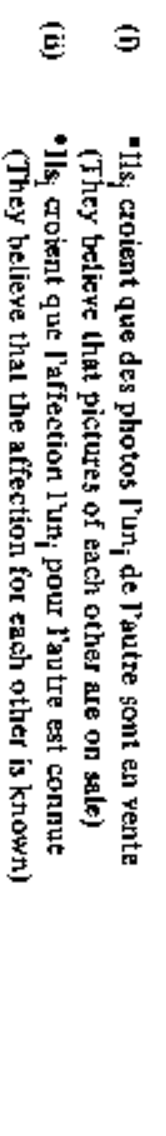

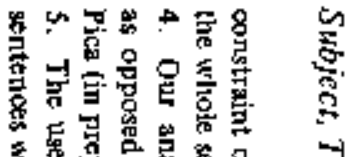

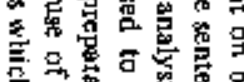

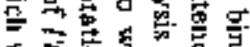

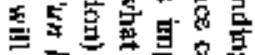

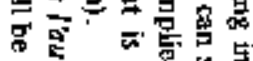

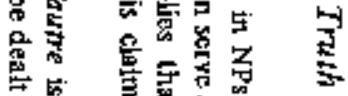
豈富

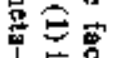

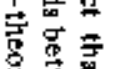
蚂常 言密莒

写总

宫点总

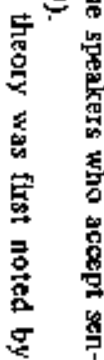

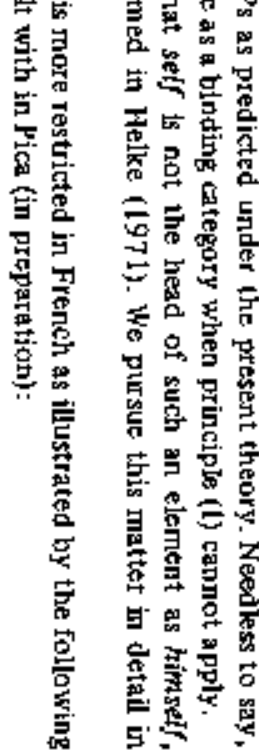




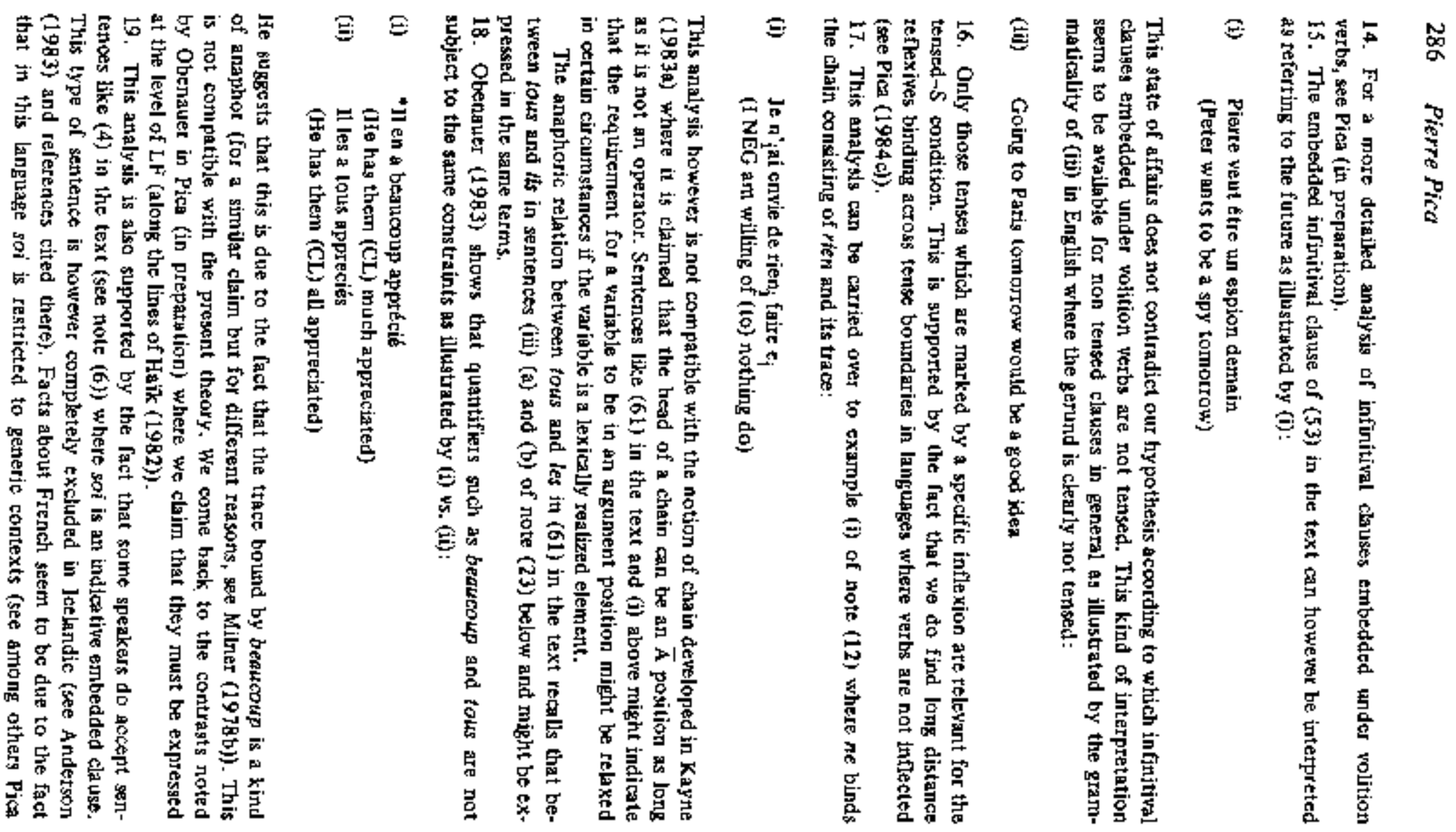

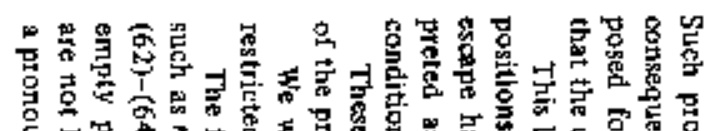

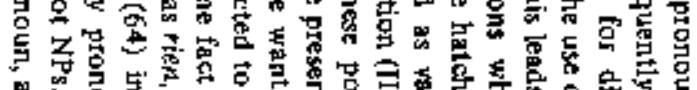

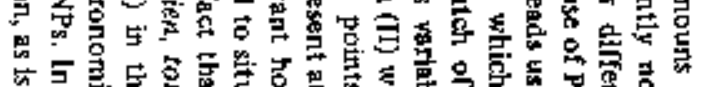

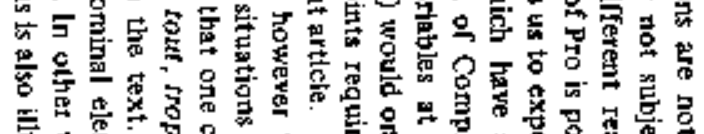

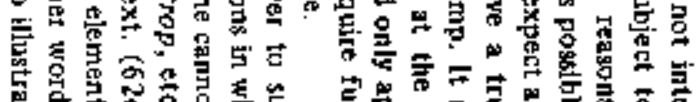

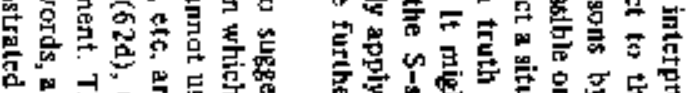

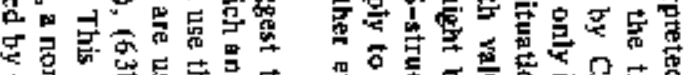

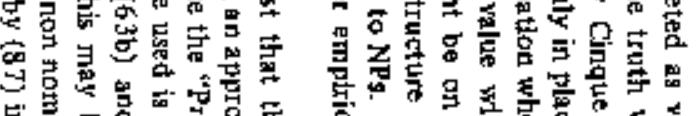

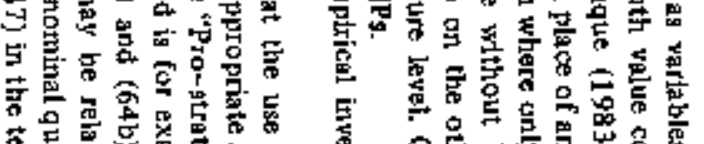

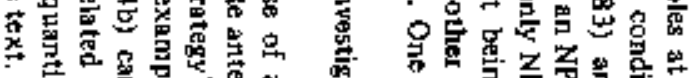

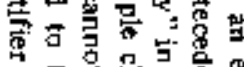

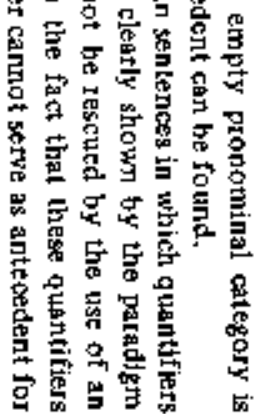

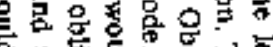

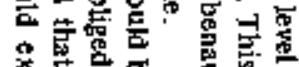

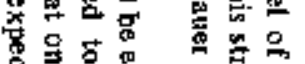

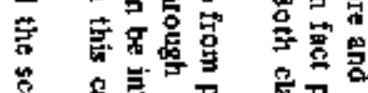

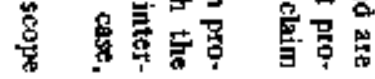

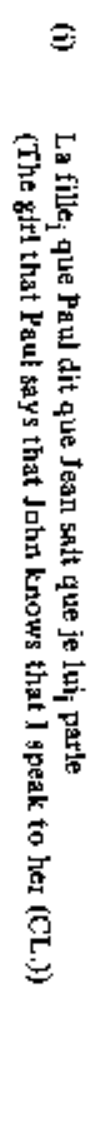

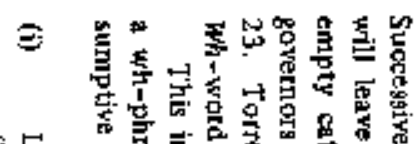

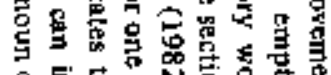

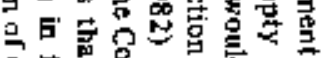

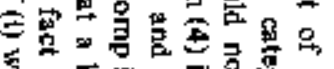

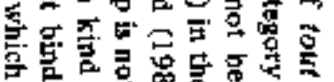

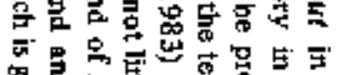

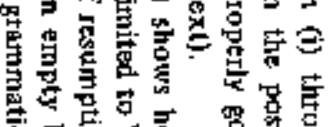

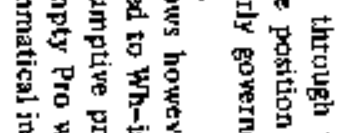

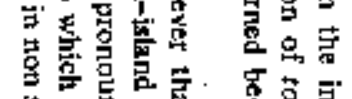

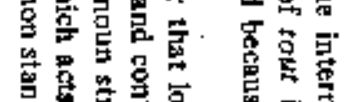

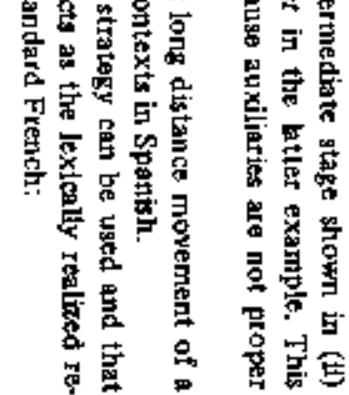

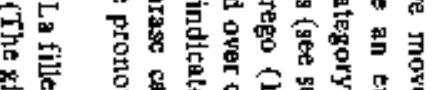

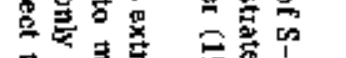

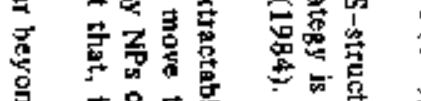

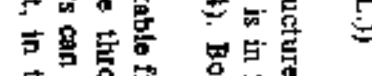

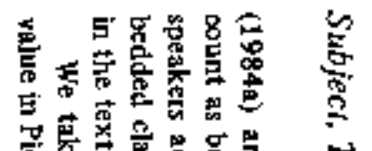

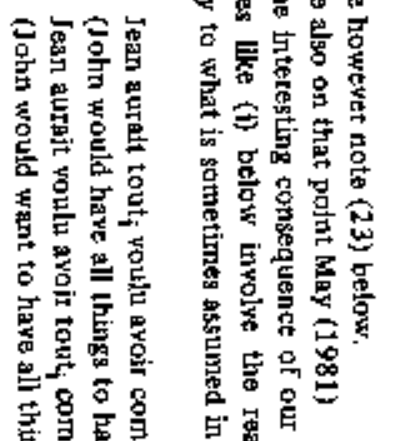

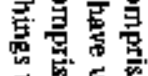

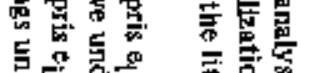
휼 焉焉 声:

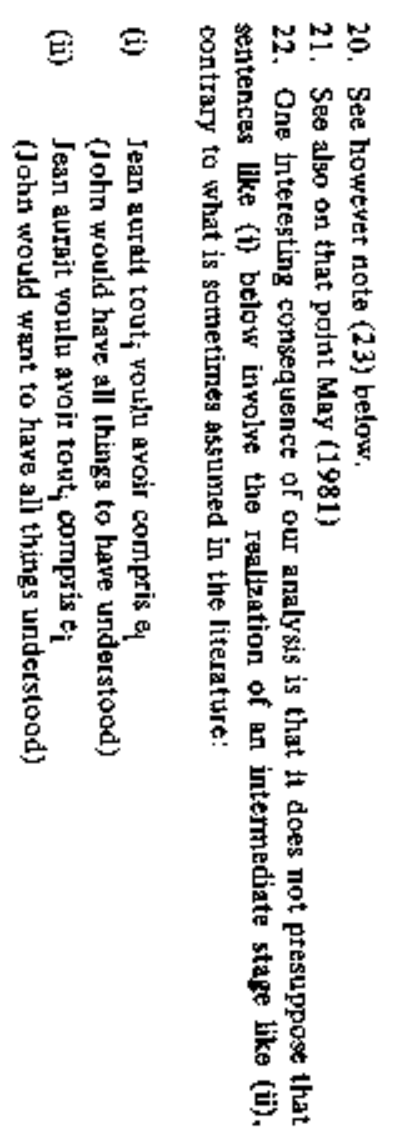

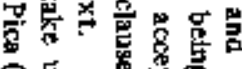

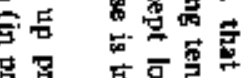

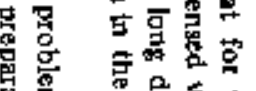

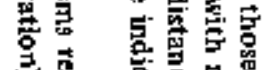

哈

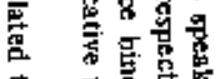

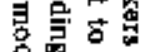

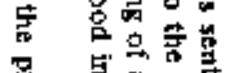

总总要霓

光 可员

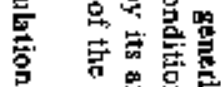

울

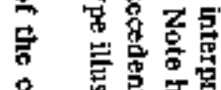

8 要要

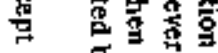

号它芦若

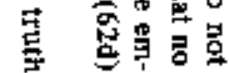

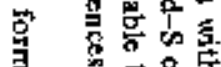




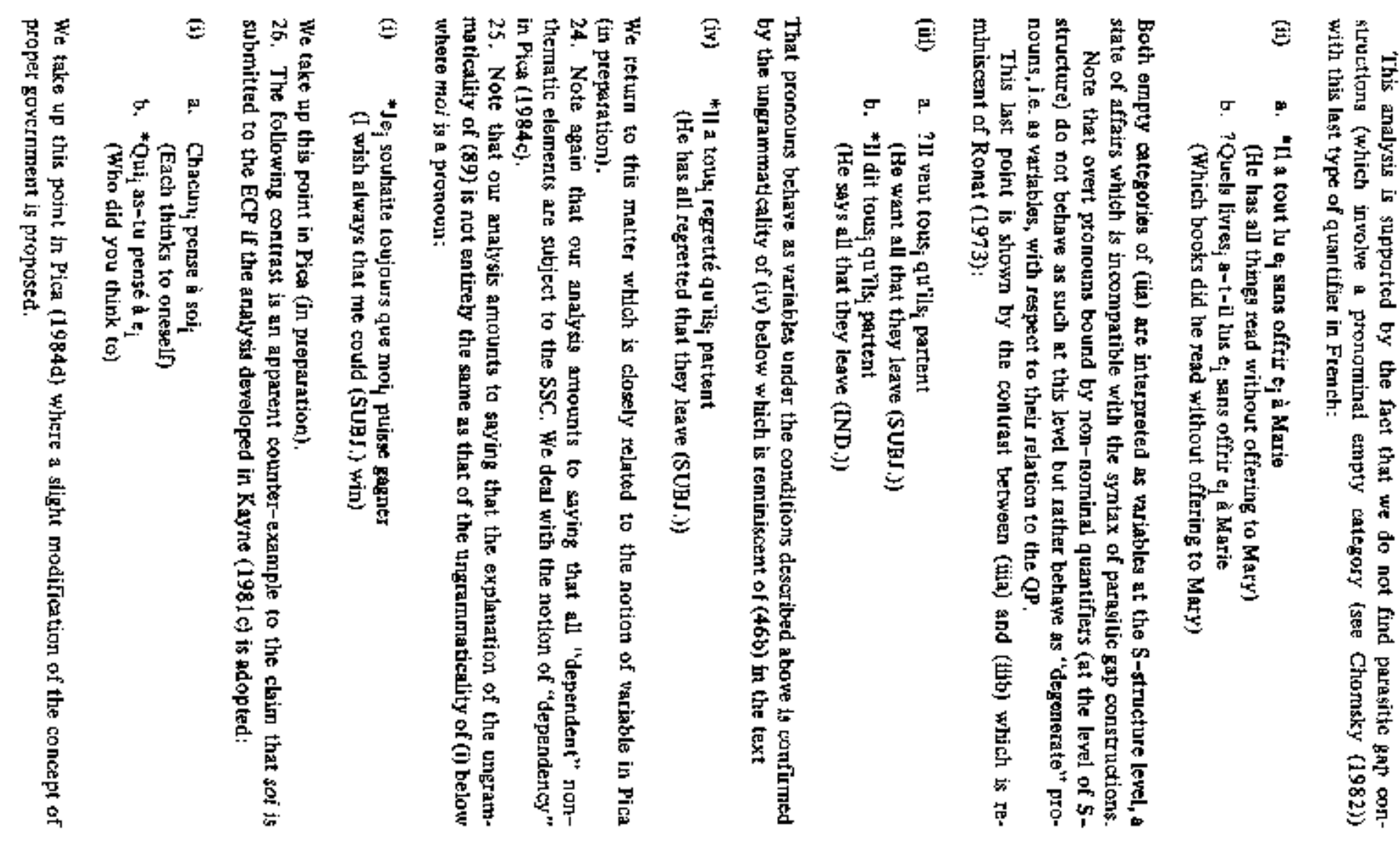

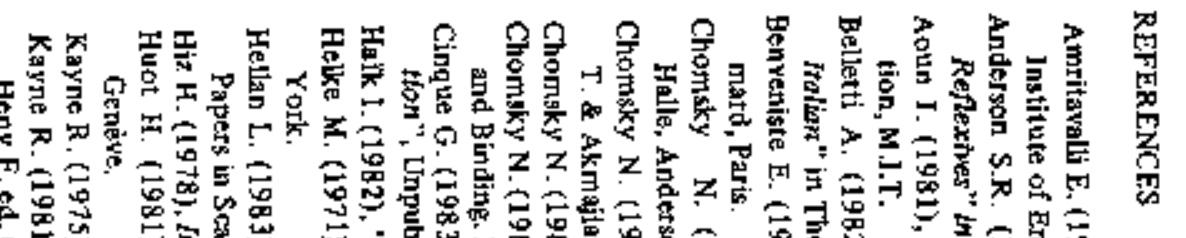

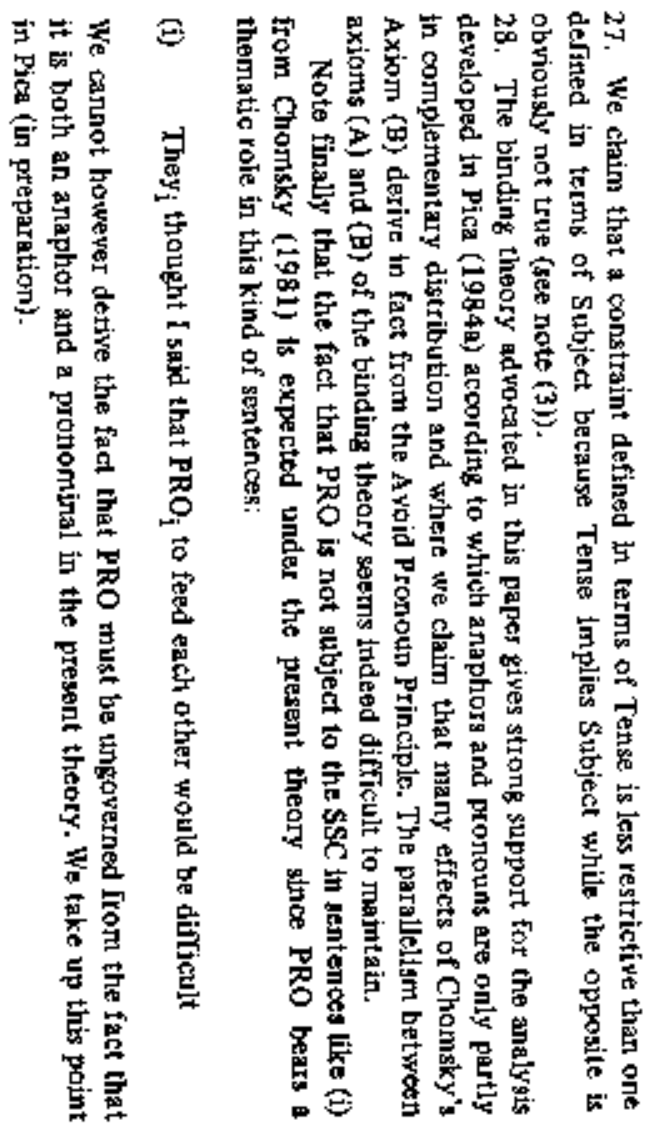
蒁 


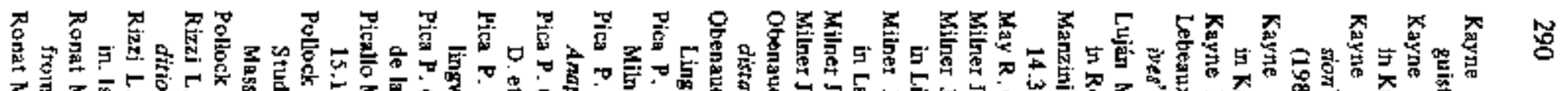

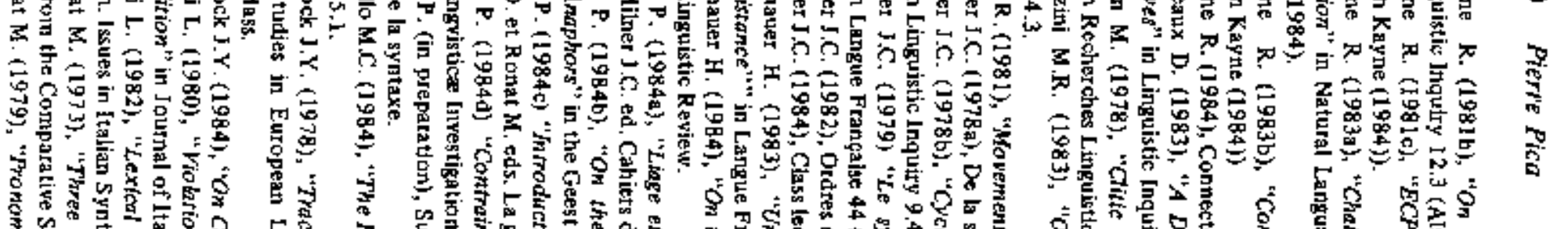

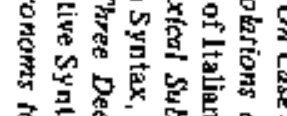

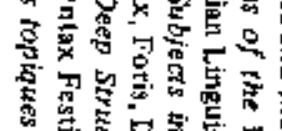

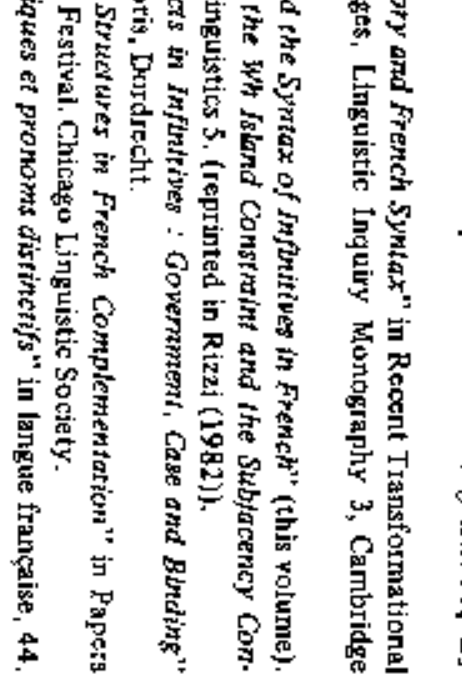

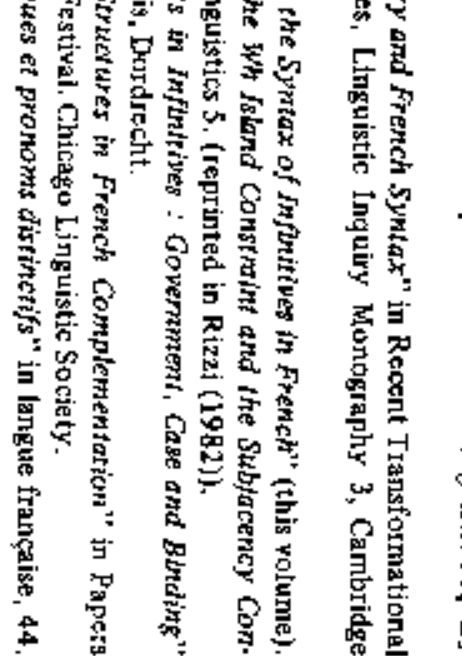

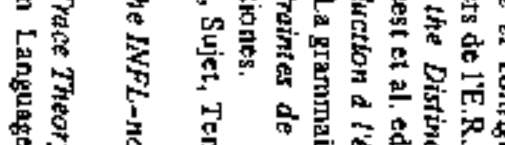

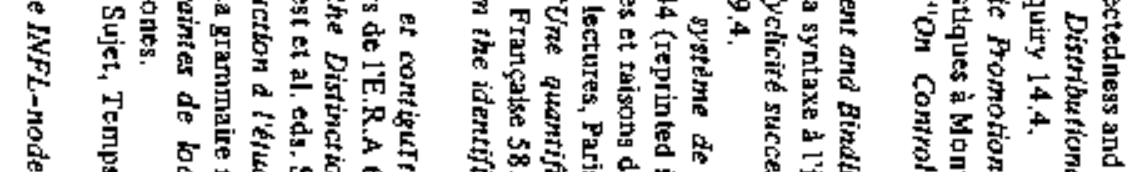

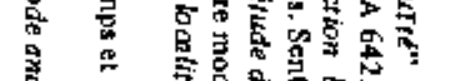

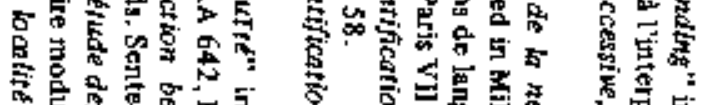

ํ.

焉

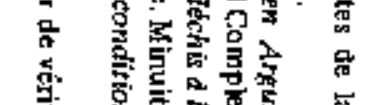

:

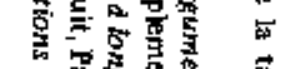

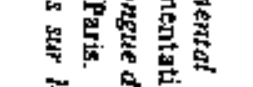

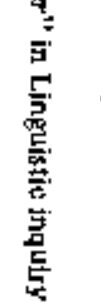

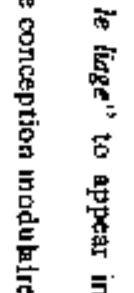

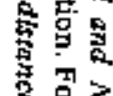

营

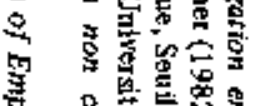

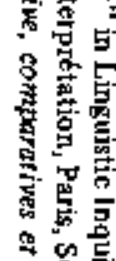

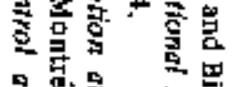

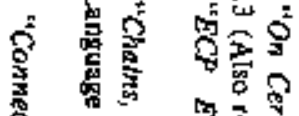

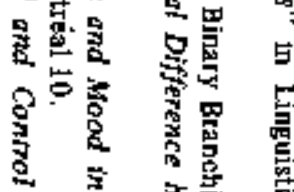

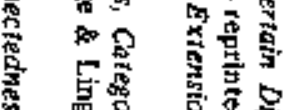

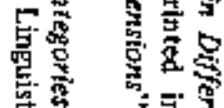

空

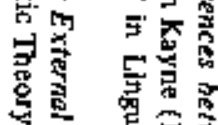

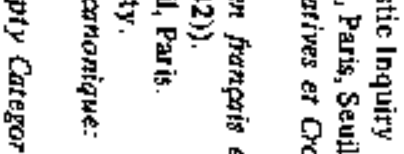

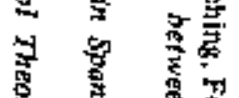

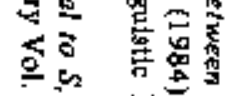

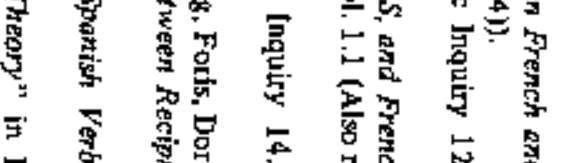

औ

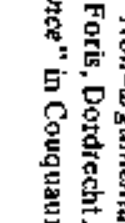

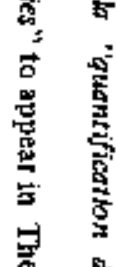

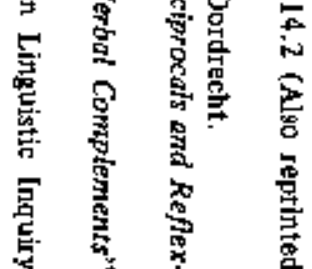

壁

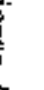

